\title{
Learning through the Experience of Water in Elementary School Science
}

\author{
Amanda R. Levy *(i) and Felicia Moore Mensah
}

check for updates

Citation: Levy, A.R.; Moore Mensah, F. Learning through the Experience of Water in Elementary School Science. Water 2021, 13, 43. https://doi.org/ 10.3390/w13010043

Received: 9 October 2020

Accepted: 23 December 2020

Published: 28 December 2020

Publisher's Note: MDPI stays neutral with regard to jurisdictional claims in published maps and institutional affiliations.

Copyright: () 2020 by the authors. Licensee MDPI, Basel, Switzerland. This article is an open access article distributed under the terms and conditions of the Creative Commons Attribution (CC BY) license (https: / / creativecommons.org/ licenses/by/4.0/).
Department of Mathematics, Science and Technology (MST), Teachers College, Columbia University, 525 West 120th Street, P.O. Box 210s, New York, NY 10027, U; fm2140@tc.columbia.edu

* Correspondence: arl2163@tc.columbia.edu

\begin{abstract}
To date, limited research has been done on the implementation of experiential learning among elementary school students. The current mixed-methods study examines the capacity of elementary science students to develop water literacy through the application of an experiential learning framework. From 2016-2017, two sections of 6th-grade science students $(n=56)$ from a gifted and talented school in Queens, NY, were introduced to an experiential-based water curriculum designed to meet the needs of elementary science standards through the use of authentic learning environments, physical and conceptual modeling, and systems thinking. Multiple research instruments were used as formative and summative assessments to determine baseline understanding and quantify the consequences of student learning: pre- and post-tests and pre- and post-drawing assessments, science notebooks, field journals, reflections, and observations. After participation in the experiential water unit, most students increased their conceptual understanding of water cycle components and processes from surface to groundwater, physical properties of matter, and hydrogeological concepts of permeability and porosity. Systems thinking skills progressed over the unit from structural thinking to dynamic thinking. Implications of this study indicate that the experiential learning framework is an effective pedagogical tool for elementary science students to develop water literacy and science and engineering practices.
\end{abstract}

Keywords: water; experiential education; elementary school science; geoscience; systems thinking skills; next generation science standards

\section{Introduction}

An understanding of where water is found in the world is fundamental to hypothesizing how hydrological systems work and grasping concepts in earth and environmental science [1-4]. The nature and practice of elementary school science standards place expectations on students to recognize ecosystem processes and observe, describe, and carry out experiments to investigate water phenomena. Contrary to this learning objective, elementary students hold many misconceptions about hydrological systems. Students come to school with an existing schema of water in the environment that can be informed and misinformed by cultural beliefs, pseudo-scientific perceptions, everyday life, and their level of child development [4-7]. A primary goal in the practice of science is direct involvement in problem-solving the major challenges that confront society today.

A clear example of this problem is the understanding of the groundwater concept, which can simply be defined as "water that moves downward into the ground" [5-7]. Groundwater is a critical natural resource for irrigation in agriculture, industry, and public water supply. Research among students in the United States found that they generally viewed groundwater as a disconnected system with no relationship to the surrounding land, soil, and rocks [2]. Similar findings suggest that students view groundwater as a kind of pool, lake, or pipe [8]. Without water literacy of these systems, students are unable to grasp ideas around human needs for society, such as water overuse, flooding prevention, contamination, and protection [9]. Another example of this misconception is 
student understanding of the water cycle, studies among elementary-aged students have found that they have problems conceptualizing the interactions of the hydrological cycle and dynamic flow on Earth through surface and subsurface interactions [1,2,8-11].

As a result, many students struggle with the development of systems thinking, a way of thinking to explain, understand, and interpret complex and dynamic (biological)systems [11]. While these ideas are found throughout all grades, systems thinking skills are least developed among elementary students $[3,12,13]$. To address these ideas, Draper [13] proposes a systems thinking model that emphasizes the progression of specific types of thinking in a developmental sequence. He recommends that elementary grades begin with structural thinking to orient students towards recognizing simple causal relations. Structural thinking emphasizes what affects what, where things flow, and which things accumulate. The next step in the progressions is to dynamic and generic thinking, where learners can begin to recognize causal loops and patterns that cause changes in behavior over time. Research supports that elementary level students can develop higher systems thinking ability in biology [14]; Earth science [1-3,15]; biogeochemical and biological cycles [3]; watersheds [16]; and ecosystems [10,17].

In the elementary science classroom, the question 'where does my water come from' has generally been discussed on a global scale, resulting in students lacking a meaningful connection to the local water systems in their neighborhood [16-19]. In previous research, connection to these resources and conceptual understanding of hydrological flow has been facilitated through visually based instructional methods, such as field trips, hands-on experiments, and modeling $[3,19,20]$.

\subsection{Experiential Education \& Learning Theory}

Grounded within the theory of constructivism, experiential education is a method based on the pedagogical principle of learning by doing, where students experience or interact with their ideas in the construction of knowledge [21-24]. Dewey's theory of experiential education [25] is based upon the idea of the continuum of experience; in other words, students learn best when new ideas are connected to prior knowledge. Experiential education is a construct that associates the relationship between the individual and the environment as a pathway to knowledge $[22,24,25]$. In this process, students acquire knowledge from being actively engaged or after having experienced or taken part in a new activity or assignment [26].

Kolb's experiential learning theory focuses more on the process, relying on the transformation of knowledge through activation and reflection for learning to occur [27]. The theory is represented by a model of the cyclic process that learners use to determine how they approach problem-solving (Figure 1). Learners grasp information through concrete experiences and abstract concepts and can then transform the experience or concept to make meaning in their world through reflective observation and active experimentation. This model encourages the learner to participate in identifying and activating new discoveries, while concurrently exploring scientific processes through the components and context of each experience. The experiential learning model represents a continuum of learning as a continually recurring problem-solving process.

In practice, the experiential learning model provides a framework for scientific instruction focused on fostering children's natural curiosity and the development of skills to produce, interpret, and quantify information from the world around them. The model prompts students to question, think critically, test, and make conclusions. Taken together, Dewey's [25] and Kolb's [27] theories are complementary and combine as a framework in this research to tell a story of students' water literacy before, during, and after their experience of participating in a water-based curriculum. From the extensive search of the literature, the implementation of experiential education theory as a framework for teaching and learning has predominantly been within adult education and professional development settings outside of the domain of science [27]. By introducing experiential methods into the elementary science classroom, we were able to further the scope of the 
educational process and engage students in a meaningful and motivating context to learn more about water, systems, and models. Learning through experiential practice can become significantly more dynamic as it allows the development of skills, such as confidence, independence, and student autonomy, which also enhances positive attitudes toward learning [28].

\section{Concrete Experience (doing / having an experience)}

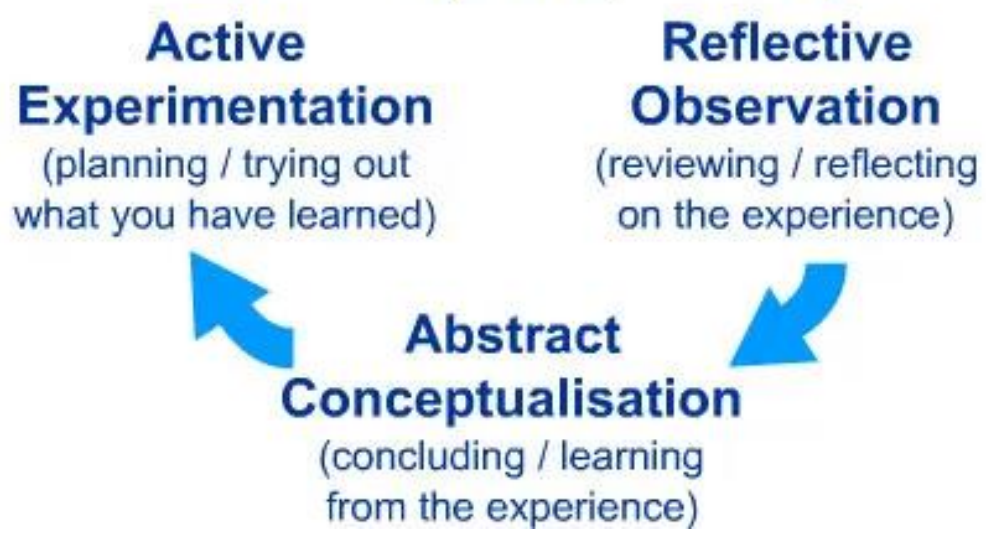

Figure 1. Experiential Learning Model [27].

\subsection{Systems and System Models}

Used in this context, the experiential framework aligns well with the vision of the Next Generation Science Standards (NGSS), that students progressively engage in scientific and engineering practices to address the challenges that face humanity and enrich their understanding of the core ideas [6]. The NGSS is based on three dimensions of learning that provide students with a context to understand science content and connect concepts across disciplines. The first dimension, science and engineering practices (SEP) encompasses the major practices that scientists use as they investigate the world around them. This includes designing and building systems and exploring theories and models. The second dimension, crosscutting concepts (CCC), are defined as "ideas and practices that cut across the science disciplines" [6] (pp. 16-17). The third dimension, the disciplinary core idea (DCI), is based on criteria that an idea can be used as a tool for problem-solving, understanding subject matter across numerous disciplines and clarifying key science principles within one single discipline. In the NGSS, the four major domains represented are the physical sciences, life sciences, earth and space sciences, and engineering, technology, and applications of science.

This same systems perspective is advocated by the National Academy of Science, which encourages school science practice to be understood as a series of systems, synergistically built upon the foundations of past achievements and tie the "global gap of well-being, the fate of humanity to the progression of scientific ways of knowing and spread of scientific culture" [29] (p. 63). How we think about hydrological systems can be viewed through the lens of systems thinking, a conceptual framework of knowledge, principles, and tools that enable us to observe the interrelations and mutual connections necessary to determine changeable patterns and repeated phenomenon [30]. A systems thinking approach to school science practice introduces students to a way to explain, understand, and interpret complex and dynamic (biological) systems [11].

The NGSS introduces the concept of systems thinking through the cross-cutting concept of systems and system models to "help students deepen their understanding of 
the disciplinary core ideas, and help students to develop a coherent and scientifically based view of the world" [6] (p. 79). To meet the performance expectations of Earth and Space systems, the NGSS recommends that students demonstrate an understanding of the significant role of water in the Earth's processes by modeling the movement of water through the states of matter via a physical or conceptual manifestation. Understanding the movement of water and states of matter is challenging for young elementary students. Although they possess basic cognitive forms of organizing and representing data that allow them to represent causality, they often do not have the theoretical knowledge or cognitive ability to see these patterns in the data they are collecting [10,31]. As a result, elementary school students have difficulty understanding complex causal relationships and patterns in natural phenomena and struggle to recognize simple cyclic patterns, the transformation of the states of matter, and the belief that groundwater and surface water are separate.

The study presented in this paper seeks to address these ideas through the implementation of an experiential-based water engineering curriculum; specifically, the curriculum considers the learning process through the lens of the experiential learning model to enrich students' understanding of hydrological concepts and connect their understanding to multiple disciplines in science. Students in this study interacted with water through multiple representations in concrete field experiences, water sampling, and modeling. In studying the New York City water supply and visiting local waterbodies, this intervention created a local context, intending to create stewardship and meaningful connections for students to their community water resources and to examine how human uses of local land and water resources impact water quality and the needs of society. To develop an understanding of how an experiential-based curriculum can address elementary students' learning about hydrological systems, this study was guided by the following research questions:

(1) How does participation in an experiential learning water unit improve student understanding of hydrological concepts and processes?

(2) How does participation in an experiential learning water unit facilitate student understanding of complex systems?

\section{Materials and Methods}

\subsection{Creating the Experiential Water Unit}

During the 2016-2017 school year, the first author (a specialist in the field of water ecology and environmental science) worked directly with an elementary science teacher to create an experiential water unit for students to explore water science and engineering through their local water systems. The unit content draws from the three dimensions of learning from the Next Generation Science Standards (NGSS) Earth Science framework [6], the New York City (NYC) 6-12 Earth Science Scope and Sequence [32], and adaptations from the Engineering is Elementary@ (EiE), Water, Water, Everywhere curriculum [33].

Before the start of the school year, the first author created and facilitated four one-onone professional development sessions for the classroom science teacher covering topics in experiential learning theory, hydrology, and the NGSS. The culminating project for the teacher was to create an experiential-based unit plan that provided students with a learning sequence on watersheds and water quality, modeling, and water systems in thelocal context of the New York State water supply. The final unit plan included student work products, such as water research projects, laboratory reports, and reflection essays, as well as the research instruments created for this study, distinguished in the unit plan from the other assignments by bold type (Appendix A). Over the school year, a scientist-teacher mentorship was developed that increased the teacher's confidence and ability to teach elementary science topics [34] Details of this mentorship are documented by the author in academic research [35].

\section{Experiential Learning Framework}

For this study, the EiE Water, Water, Everywhere curriculum was redesigned to incorporate the experiential learning model [27] as a framework to carry out science and 
engineering practices from the NGSS. The experiential learning model guided the lesson planning for the unit on watersheds and water quality. Metacognitive strategies provided the rationale for the inclusion of assessments. The framework operated on a continuum grounded by a concrete experience, reflective observation, abstract conceptualization, and active experimentation. The sequence of the unit was used to explore and discuss the concept of water filtration through connections between the scientific study of water and the water cycle, Earth's role in water processes, and the role of technology and engineering in providing clean and healthy water.

The EiE unit modified for this research, Water, Water, Everywhere, introduced the problem of water pollution through the social and cultural context of a young girl in India observing the Ganges river near her home and extracting water to create a habitat for her pet turtle. For the redesign, instead of experiencing the everyday world of the storybook protagonist, the students connected learning to their local environment and viewed the problem through their own worldview. Students were introduced to watersheds and field sampling by immersing them in authentic scientific inquiry through experiential learning. The learning framework of the experiential water unit brought together these multiple sources with the learning objective to promote conceptual understanding of water cycles, water filtration, groundwater, porosity and permeability, engineering design, and representations of hydrology in earth systems (Table 1).

\subsection{Participants and Setting}

Participants for this study were drawn from two different 6th-grade science classrooms, class \#1 $(n=28)$ and class \#2 $(n=28)$ attending the Avenue School (pseudonym), a gifted and talented school located in Queens, NY. Many students identified their race and ethnicity as Asian, followed by White, Hispanic, and Black (Table 2). The racial and ethnic makeup of the school was not representative of the diversity of residents within the community and represented less than $10 \%$ of the district population.

The research setting for this study was on-site in the science classroom at the Avenue School and off-site at two different bodies of water, the Bronx River and Hallett's Cove, a tributary of the East River located walking distance from the school building with waterfront access. The field sites were included to foster environmental stewardship and provide a direct experience in the natural world. The unit plan progressed from looking at water on Earth to learning about the New York City Watershed to direct experiences with local waterbodies. The scope of the lessons considered water movement and flow beginning with the modeling of runoff in a watershed and ending with modeling infiltration through layers of soil to represent groundwater.

The unit was taught over five class sessions, with field experiences and science laboratories. Each unit session was taught by the science classroom teacher with the study's first author as a participant-observer. In the field experiences, students explored shoreline ecology and conducted water quality sampling (for the parameters of temperature, $\mathrm{pH}$, nitrogen, dissolved oxygen, and specific conductivity). One of the field experiences was part of a program sponsored by the New York State Department of Conservation (NYSDEC) and Columbia University's Lahmont Doherty Earth Observatory Laboratory: A Day in the Life of the Hudson and Harbor, also known as Hudson River snapshot day [36]. New York state educators that participate in this annual event are trained to work with water equipment and on the day of the event, work with their students to provide a snapshot of the biota, water movement and water quality of the Hudson River and adjacent harbors. On the day of the event, NYSDEC was on site at Hallett's Cove and brought field equipment with them that included soil cores, seine nets, and turbidity tubes for the students to use as part of their experience. In the science laboratory sessions, students analyzed water quality results and designed and constructed water filtration models in small groups of three (triads). Students used a science notebook and field journal in both learning environments to record data and reflect on their scientific observations. 
Table 1. Learning Framework for Experiential Water Unit.

\begin{tabular}{|c|c|c|c|c|c|}
\hline $\begin{array}{c}\text { Lesson } \\
\quad \#\end{array}$ & $\begin{array}{l}\text { Experiential Learning } \\
\text { Component }\end{array}$ & $\begin{array}{l}\text { Experiential Water } \\
\text { Curriculum }\end{array}$ & $\begin{array}{l}\text { Disciplinary } \\
\text { Core Idea }\end{array}$ & $\begin{array}{c}\text { Science and } \\
\text { Engineering Practices }\end{array}$ & $\begin{array}{l}\text { Cross Cutting } \\
\text { Concept }\end{array}$ \\
\hline 1 & $\begin{array}{l}\text { Concrete Experience } \\
\text { Reflective Observation }\end{array}$ & $\begin{array}{l}\text { Introduction to Field } \\
\text { Sampling: Field } \\
\text { Sampling at Bronx } \\
\text { River }\end{array}$ & $\begin{array}{l}\text { Abiotic Factors, } \\
\text { Water Quality, } \\
\text { Hydrology }\end{array}$ & $\begin{array}{l}\text { Planning and } \\
\text { Carrying Out } \\
\text { Investigations, } \\
\text { Analyzing and } \\
\text { Interpreting Data }\end{array}$ & $\begin{array}{l}\text { Energy and Matter, } \\
\text { Patterns, Stability } \\
\text { and Change }\end{array}$ \\
\hline 2 & $\begin{array}{c}\text { Concrete Experience } \\
\text { Reflective Observation } \\
\text { Abstract Conceptualization }\end{array}$ & $\begin{array}{l}\text { Using Field Data: } \\
\text { Field Sampling at } \\
\text { Hallett's Cove } \\
\text { Abiotic Factors } \\
\text { Laboratory }\end{array}$ & $\begin{array}{l}\text { Abiotic Factors, } \\
\text { Water Quality, } \\
\text { Hydrology }\end{array}$ & $\begin{array}{l}\text { Planning and } \\
\text { Carrying Out } \\
\text { Investigations, } \\
\text { Analyzing and } \\
\text { Interpreting Data }\end{array}$ & $\begin{array}{c}\text { Energy and Matter, } \\
\text { Patterns, Stability } \\
\text { and Change, Cause } \\
\text { and Effect, }\end{array}$ \\
\hline 3 & $\begin{array}{l}\text { Concrete Experience } \\
\text { Reflective Observation } \\
\text { Abstract Conceptualization } \\
\text { Active Experimentation }\end{array}$ & $\begin{array}{c}\text { Earth Materials Lab- } \\
\text { oratory:Exploring } \\
\text { Permeability and } \\
\text { Porosity in Earth } \\
\text { Materials }\end{array}$ & $\begin{array}{l}\text { Hydrology, Earth } \\
\text { Science }\end{array}$ & $\begin{array}{l}\text { Planning and } \\
\text { Carrying Out } \\
\text { Investigations, } \\
\text { Analyzing and } \\
\text { Interpreting Data }\end{array}$ & $\begin{array}{c}\text { Patterns, Scale, } \\
\text { Proportion \& } \\
\text { Quantity, Cause and } \\
\text { Effect }\end{array}$ \\
\hline $4 \& 5$ & $\begin{array}{l}\text { Concrete Experience } \\
\text { Reflective Observation } \\
\text { Abstract Conceptualization } \\
\text { Active Experimentation }\end{array}$ & $\begin{array}{c}\text { System Modeling } \\
\text { Laboratory: } \\
\text { Design and Redesign } \\
\text { of Water Filtration } \\
\text { Models Using Earth } \\
\text { Materials }\end{array}$ & $\begin{array}{c}\text { Engineering } \\
\text { Design, Model } \\
\text { Based Inquiry, } \\
\text { Hydrology, Earth } \\
\text { Science }\end{array}$ & $\begin{array}{l}\text { Developing and Using } \\
\text { Models, Planning and } \\
\text { Carrying Out } \\
\text { Investigations, } \\
\text { Constructing } \\
\text { Explanations and } \\
\text { Designing Solutions }\end{array}$ & $\begin{array}{c}\text { Patterns, Scale, } \\
\text { Proportion \& } \\
\text { Quantity, Cause and } \\
\text { Effect, Systems and } \\
\text { System Models }\end{array}$ \\
\hline
\end{tabular}

Table 2. Summary of Avenue School Characteristics.

\begin{tabular}{cc}
\hline Characteristic & Measure \\
\hline Grade levels served & $\mathrm{K}-8$ \\
Total enrollment & 370 \\
6th grade enrollment & 90 \\
$\%$ of students qualifying for free or reduced-price lunch & $100 \%$ \\
$\%$ of Asian students & $43 \%$ \\
$\%$ of Black students & $6 \%$ \\
$\%$ of Hispanic students & $9 \%$ \\
$\%$ of White students & $32 \%$ \\
$\%$ of students designated as Limited English & $1 \%$ \\
$\%$ of students with Special Needs & $6 \%$ \\
$\%$ of teachers with fewer than 3 years of teaching & $40 \%$ \\
\hline
\end{tabular}

Sample collection from more than one field site presented an opportunity to include the NGSS science and engineering practice of analyzing and interpreting data. Using this approach, students were able to correlate sample results and explore differences and similarities across content as part of the water science labs. Scientific practices during the modeling laboratory sessions aligned well with concepts introduced in the 6th grade New York State Common Core Mathematics curriculum [37], such as rates and ratios, area and volume problems, and statistics. At the end of the entire unit, students completed a water filter reflection assignment created by the first author and administered by the teacher as a summative assessment (Appendix B).

\subsection{Data Collection \& Analysis}

The research approach for this study was a mixed-methods case study designed to explore the efficacy of an experiential learning framework for student understanding of core hydrological concepts and complex systems in elementary school science. Qualitative meth- 
ods were chosen for a more in-depth exploration to understand and reconstruct student experiences. Throughout the data collection process, the authors' notes and observations were continuously examined through an inductive style of analysis to identify themes and trends that emerge from the data, after collection, rather than being defined in the initial data [38-40]. Quantitative analysis was conducted to gather empirical evidence to establish relationships between the measured variables of student conceptions, and aptitude of both classrooms of elementary science students [38-40].

To address both research questions and measure students' cognition of the scientific content, data collection included the following quantitative instruments: a unit pre-test and post-test, and pre- and post-drawing assessments and the following qualitative instruments: observations of student discussions, a water filter reflection assessment, and student artifacts in the form of science lab notebooks and field journals. Pre- and post-unit tests (Appendix C), and pre- and post-drawing assessments were administered by the classroom teacher at the start and end of the experiential water unit. Both instruments served as formative and summative assessments to evaluate students' conceptual understanding of water phenomena and complex systems. All research instruments, informed consent, participants' rights, and assent forms for minors were reviewed and approved by the Teacher College, Columbia University, Institutional Review Board (Protocol Number: number 16-361). Before any data was collected, parents completed informed consent and students completed an assent form for minors.

Unit pre- and post-tests were scored out of a total of 100 points and consisted of multiple-choice, true-false, diagrams, and open-ended questions. There was a total of 21 questions on the pre-test and 22 questions on the post-test with the addition of a multiplechoice question based on the students' water modeling labs. Questions on the post-test were weighted accordingly to accommodate this additional question. To score both the preand post-unit tests, a t-test statistic and one-way analysis of variance were calculated with SPSS@ software, (IBM, Armonk, NY, USA) to analyze patterns of statistically significant change or consistency between the pre-test and post-test results. Since data in the preand post-test were similar, a two-sample paired, or "pooled" $t$-test was used to assess the difference between the means based on two independent random samples.

Drawing assessments were included in the study as a learning strategy to connect to student's mental models of water systems, and then use this as a blueprint to build representative models to solve problems. The classroom teacher presented students with the essential question of the unit- "Where does water come from and where does it go in nature?"- - to guide students' drawings. Students were asked to label their drawings to identify water components and processes. Pre- and post-unit drawing assessments were analyzed using a coding framework created by the authors that combined scoring components from Rennie and Jarvis children's drawing rubric [41] and Draper's systems thinking scale [13] (Appendix E). Students who were not comfortable drawing were encouraged to annotate or add sentences to their drawings to provide clarification of their understanding. Students could receive a total score of 25 points, based on their inclusion of water cycle components, water cycle process, and ability to identify system relationships and cycle perceptions. Drawing assessments were graded by the first author with the assistance of two colleagues that work as research scientists in water science and engineering. To measure inter-rater agreement, a scale developed by Landis and Koch [42] was used to designate a score of zero as no agreement, $0-0.20$ as poor agreement, $0.21-0.40$ as fair agreement, $0.41-0.60$ as moderate agreement, and $0.61-0.80$ as a significant level of agreement. The resulting inter-rater agreement had a kappa statistic of 0.48 , moderate agreeability. To compare and analyze patterns of statistical significance between the pre- and post-drawing assessments, a paired $\mathrm{t}$-test was used to test the difference between the means, and two-way analysis of variance was calculated with SPSSC software (IBM, Armonk, NY, USA).

Analysis of science lab notebooks, field journals reflections, open-ended questions, and classroom observations were conducted through open coding and line by line coding to look for patterns, and then with axial coding to identify themes and link categories 
to subcategories to define emergent themes [43] The initial qualitative review was done through open coding, specifically creating codes with words that reflected actions, such as "water going through gravel" or "flowing through a pipe". Then, these same documents were reviewed via line-by-line coding to confirm patterns, breaking up the data to define the actions. Initial trends showed that students used similar approaches in their practical science applications and processes in their water filtration model design, breaking down each component to illustrate patterns and define pathways of water movement. Documents were then reviewed with axial coding to identify themes and link categories to subcategories with the intention that through this process, we would start to see some emergent themes. For example, one emergent category was student perceptions of permeability and porosity, so subcategories for this included "sucked up water", "stop and block" and "filter and clean". Through the lens of the experiential framework, we could make sense of the data in the subcategories by connecting it to explanations derived by students through active experimentation and abstract conceptualization. An explanation for "sucked up water" could be that the sand in their model is not filtering the water, just absorbing it. Table 3 provides insight into the laboratory sessions and the emergent patterns and themes that allowed students to make conclusions about the movement of water through their model, the permeability and porosity of different materials, and how these factors contributed to water quality. Since the modeling sessions were a culminating activity of the experiential unit, there is reason to believe that students' conceptual understanding of these processes was informed by their field sampling experiences and classroom discussions and reflections that enabled students to make meaningful connections to these experiences.

Table 3. Qualitative Text Analysis of Water Concepts and Processes.

\begin{tabular}{|c|c|}
\hline Experiential Approach & Emergent Themes \\
\hline Active experimentation & $\begin{array}{l}\text { Changed filter to have more gravel: } \\
\text { addition of gravel to block sand } \\
\text { addition of gravel to trap soil and dirt }\end{array}$ \\
\hline $\begin{array}{c}\text { Abstract } \\
\text { conceptualization }\end{array}$ & $\begin{array}{l}\text { Gravel most porous } \\
\text { Gravel blocks dirt } \\
\text { Sand cleaned the water }\end{array}$ \\
\hline
\end{tabular}

\subsubsection{Research Question One}

To answer research question one, the experiential learning model [27] was used to interpret how students processed their concrete experiences from the field to guide problem-solving approaches in their scientific practices in the classroom.

Pre- and post-test scores provided an empirical measure of progress to evaluate student performance. The pre- and post-unit tests were constructed based on water concepts from EiE@ activities, Earth Science concepts from Libarkin and Anderson's Geoscience Concept Inventory [44], and published documentation of water cycle misconceptions $[1,2,8,11]$. The unit test questions addressed student misconceptions about surface and subsurface water movement, with emphasis on the following misconceptions: (1) water flows beneath the ground in the form of underground lakes, rivers, and streams, and (2) groundwater and surface water are separate. Many students left blank spaces on both the pre- and post-tests, which created a potential confounding factor in the analysis of student performance following the curriculum intervention. To rectify this, the first author grouped the pre- and post-test responses by concept/subject area, level of difficulty, and question 
type (Table 4). Due to differences between groupings, question types and point values we could not assume that there was normal distribution with this specific data set. To analyze the variance between pre- and post-test questions by concept (biotic factors, earth science, environmental science, hydrology, water cycle, water filtration, and water engineering), ordinal level analysis was conducted to tabulate the total correct and incorrect answers, and then percent differences were calculated for each of these subject areas. The rationale was that, by grouping in this way, we would be able to observe the variance in conceptual proficiency in a meaningful way for each subject area from the pre- to the post-test.

To examine how students documented their experiences in science notebooks, field journals, classroom observations, and open-ended questions from the pre- and post-test, there were four iterations of inductive and constant comparative review. These analyses were conducted to compare key similarities and differences in qualitative student data. The first two cycles of coding resulted in generating themes, as well as those that emerged from the participants' language, or what is referred to as in vivo codes [43,45]. Pre- and postdrawing assessments were analyzed using a coding framework created by the researchers (Appendix E) and scored out of a total of 25 points based on students' conceptions of a phenomenon through their interpretation of water cycle components and processes.

Table 4. Pre and Post Test Questions by Concept Level.

\begin{tabular}{|c|c|c|c|}
\hline Question \# & Concept & Level & Question Type \\
\hline 1 & Water Cycle & Low & Multiple Choice \\
\hline 2 & Earth Science & High & Multiple Choice \\
\hline 3 & Biotic Factors & Low & Multiple Choice \\
\hline 4 & Earth Science & High & Multiple Choice \\
\hline 5 & $\begin{array}{l}\text { Environmental } \\
\text { Science }\end{array}$ & Intermediate & Open \\
\hline 6 & Water Chemistry & Low & Multiple Choice \\
\hline 7 & Hydrology & High & Multiple Choice \\
\hline 8 & Water Cycle & Intermediate & Open \\
\hline 9 & Water Cycle & Intermediate & Multiple Choice \\
\hline 10 & Earth Science & High & Multiple Choice \\
\hline 11 & Water Cycle & Intermediate & Multiple Choice \\
\hline 12 & Earth Science & Intermediate & Open \\
\hline 13 & Hydrology & High & Multiple Choice \\
\hline 14 & $\begin{array}{l}\text { Environmental } \\
\text { Science }\end{array}$ & Intermediate & Multiple Choice \\
\hline 15 & Biotic Factors & Low & Open \\
\hline 16 & Hydrology & High & Multiple Choice \\
\hline 17 & Water Filtration & Intermediate & Multiple Choice \\
\hline 18 & Water Filtration & Intermediate & Multiple Choice \\
\hline 19 & Water Cycle & Low & Multiple Choice \\
\hline 19 & Water Filtration & Intermediate & Multiple Choice \\
\hline 20 & Water Cycle & Low & Multiple Choice \\
\hline 21 & Water Engineering & Intermediate & Open \\
\hline 20.1 & Hydrology & High & Open \\
\hline 21.1 & Hydrology & High & Open \\
\hline 20.2 & Hydrology & High & Open \\
\hline
\end{tabular}

\subsubsection{Research Question Two}

To answer research question two, science notebooks, water filter assessments, classroom observations, and open-ended pre- and post-unit test questions were evaluated with a rubric adapted from Assaraf and Orion's Systems Thinking Scale (Appendix D). This scale identifies thematic categories and subcategories grounded in the data to measure understanding of the unit content through a systems perspective. It is hierarchical and ranges from the basic ability to identify components and processes within a system, like what is found in structural thinking, to the ability to think temporally $[43,45,46]$. Preand post-drawing assessments were analyzed using a coding framework created by the 
researchers (Appendix E) to record students' conceptions of the phenomenon through their interpretation of system relationships and cyclic perceptions.

\section{Results}

\subsection{Conceptual Development}

For research question 1, we asked how participation in the experiential learning unit could improve the conceptual development of hydrological concepts and processes among elementary science students. Evidence from multiple research instruments indicated that after the experiential water unit many of the participating students increased their conceptual understanding and that the concepts of condensation and infiltration, as well as permeability and porosity, were most pronounced.

Results from all student scores on the pre-test $(M=63.7, S D=10.8)$ to the post-unit tests $(M=67.6, S D=8.02)$ indicated that there were significant gains in student understanding $t(55)=1.92, p=0.0128$. Pre-test results revealed that Class \#1 $(M=66.7, S D=9.60)$ had higher test scores than Class \#2 $(M=60.7, S D=11.25)$ and were not equivalent in their prior knowledge of test concepts. Although differences were observed between the class sections in the post-test scores, more than half of all students (54\%) increased their test scores from the pre- to the post-test. Due to the many questions left blank, the authors analyzed the variance from the pre- to post-tests by question subject area. Results from this crude analysis indicated that for all students, variance was most evident from the pre-test to the post-test around concepts of hydrology, environmental, and earth science (Figure 2).

On the pre-test, the most common misconception was representation of the water cycle with only atmospheric surface components. In contrast, on the post-test, understanding developed around conceptions of downward flow with runoff, subsurface interactions (infiltration, groundwater, aquifers), and permeability and porosity. In their response to open-ended post-test question \#8, student \#49 in class section \#1 responded:

"Well, once it stops raining, it will either collect, evaporate, or infiltrate. If it evaporates, once it reaches the clouds, it condensates as part of a water droplet. Then, it rains, and the cycle starts over again." (Student \#49, class\#1, unit post-test, January 2017).

Student \#17 in class \#2 responded:

"The droplet travels through the rock's pores as it descends into the earth. When it reaches the underground soil, it travels through the pores in the soil until it reaches the underground water system." (Student \#17, class\#2, unit post-test, January 2017).

We observed qualitatively that some students also demonstrated conceptual understanding in the context of social and cultural domains, connecting the water cycle to water quality and reflecting on the needs of society. In their science notebooks, students reflected on what they learned from connecting to waterbodies. Student \#25 from class \#2 noted that:

"We can learn the quality of the water that we tested. If it is safe to swim in or not. How much of each nutrient is in the water and if it is a normal amount." (Student \#25, class \#2, science notebook, 2016).

Student \#1 from class \#2 reflected on abiotic factors, citing that:

"We can learn about dissolved oxygen and phosphate in water by doing field tests. We can also learn these things by doing water tests. We can learn how the water is to drink by a field test. Also, we can determine if the water is safe to swim in." (Student \#1, class \#2, science notebook, December 2016).

Student \#22 from class \#2 expanded this understanding and reflected in their science notebook on how the water cycle is impeded by human development:

"At the river we learned about how to go to a place and take samples of water as mini waves crashed around, sloshing poop-filled water. We also learned a lot about the gross 
trash that ends up at Hallett's Cove which probably ends up at other polluted shores"

(Student \#22, class \#2, science notebook, December 2016).

Conceptual understanding of permeability and porosity was also evident in student responses to pre- and post-test question \#7: "Which is the most important in determining the amount of groundwater that can be stored within a rock?" Multiple choice responses were (a) the rock's geologic age, (b) the rock's hardness, (c) the rock's porosity, and (d) the rocks' color. The correct response is c, the rock's porosity. From the pre- to the post-test there was a $73 \%$ increase in correct responses for both class sections. Considerable gains were also observed in students' conceptual understanding of how water gets to their tap. On the pre-test, $25 \%$ of all students left this question blank or responded that they did not know. On the post-test, only $3 \%$ of students provided a blank or incorrect response.

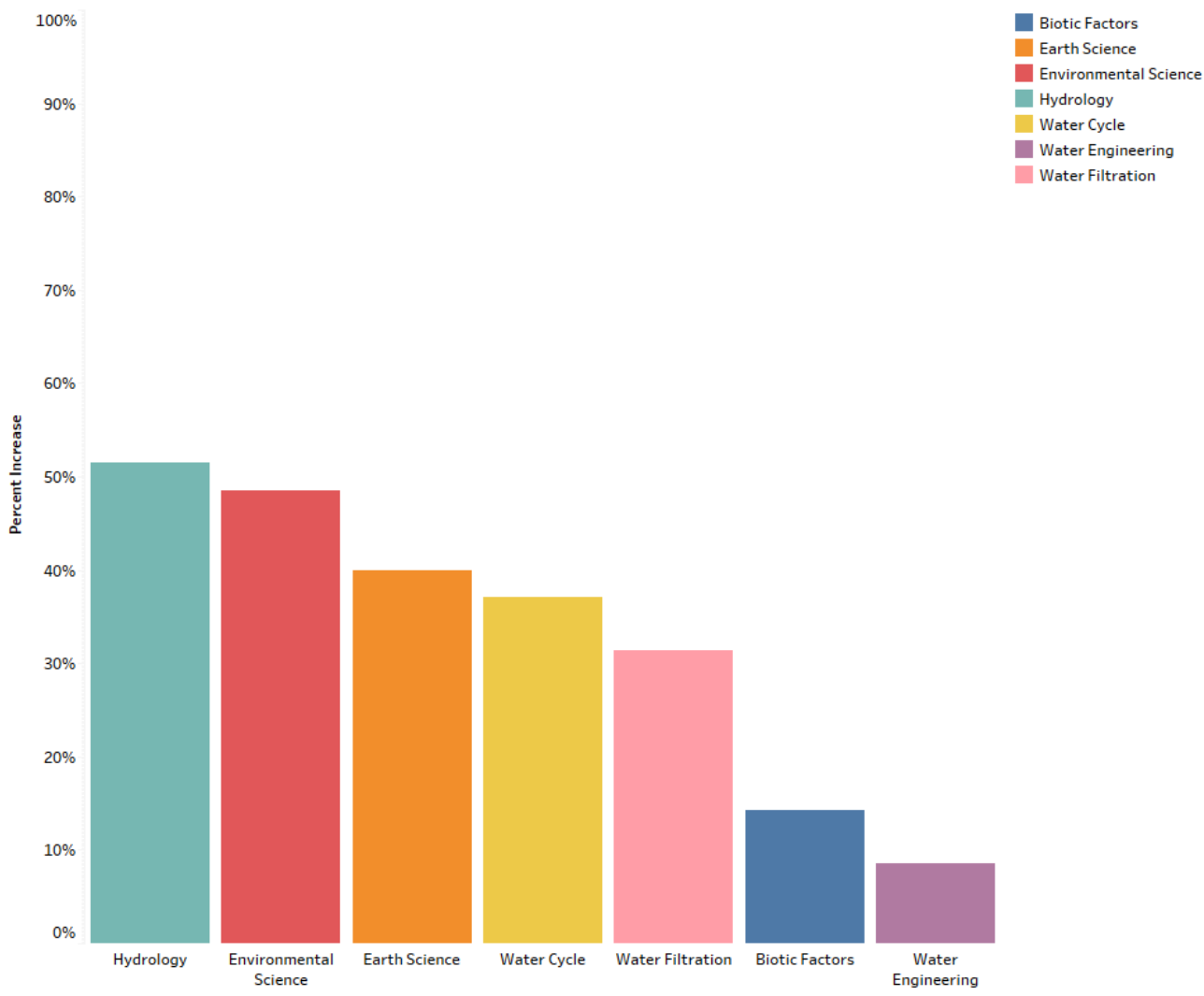

Figure 2. Total Increase in Water Component Conceptual Understanding- All Students $(n=56)$. Average percent increase for water component conceptual understanding after experiential water unit intervention. All Students, Avenue School, $2016-2017$.

Another emerging theme from the open-ended unit test questions, were student's connection to a sense of place. On the pre-test, responses to where water is found in the world was focused on a global scale, and in contrast post-test responses expanded to include local waterbodies that they had visited or had become familiar with over the course of the intervention, such as Hallett's Cove, the Catskill Watershed, the East River, the Hudson River, and the Atlantic Ocean.

For example, one student stated in their pre-test that:

"Water starts from a pipe that leads to a water filter tank." The same student responded on their post-test: "water comes from the Catskill watershed which filters water from waterbodies to my tap." (Student \#1, class \#2, pre- and post-test open-ended questions, December 2016).

Another student that left their pre-test response blank responded on the pos-test: 
"Water comes from reservoirs upstate that are part of the watershed. The water is cleaned and then sent straight to the taps." (Student \#17, class \#2, pre- and post-test open-ended questions, December 2016).

Results from all student scores on the pre-drawing $(M=14.54, S D=7.38)$ to postdrawing assessments $(M=15.7, S D=6.18)$ indicated that there was no statistically significant difference in student understanding $t(54)=0.8317, p=0.3529$. However, more than half of all students (52\%) increased their score between the two assessments, indicating that they had increased their water literacy by broadening their conceptual understanding of the components and processes of the water cycle. For this assessment, there were significant differences in learning outcomes between the two class sections. Class \#1 increased their understanding from pre- $(M=14.42, S D=7.73)$ to post-drawing assessments $(M=18.21$, $S D=4.46)$ across all water cycle components and processes, whereas scores for class \#2 decreased from the pre- $(M=13.9, S D=7.15)$ to post-drawing assessments $(M=12.53$, $S D=6.42)$ across water cycle components. Results indicated that there was a statistically significant difference in the average drawing assessment score by class section $(\mathrm{F}=6.205$, $p<0.05$ ), but not by test type (pre/post). The main effect of the class section is validated by a significant interaction effect value (Table 5).

Table 5. Two Way ANOVA Pre and Post Drawing Assessment.

\begin{tabular}{ccccccc}
\hline Source of Variation & SS & df & MS & F & $\begin{array}{c}p \text { - } \\
\text { Value }\end{array}$ & F Crit \\
\hline Sample (Class Section) & 267.2232 & 1 & 267.2232 & 6.20595 & 0.014254 & 3.929012 \\
Columns (Test Type) & 40.08036 & 1 & 40.08036 & 0.93082 & 0.336805 & 3.929012 \\
Interaction & 187.7232 & 1 & 187.7232 & 4.359655 & 0.039151 & 3.929012 \\
Within & 4650.393 & 108 & 43.05919 & & & \\
Total & 5145.42 & 111 & & & & \\
\hline
\end{tabular}

Qualitative analysis indicated that some students improved their conceptual understanding of underground water movement. Like the pre-unit test results, pre-drawing assessments included an understanding of the hydrological concepts and processes focused solely on surface components (i.e., evaporation, condensation, and rainfall) and ignored subsurface and environmental components (Figure 3).

In the post-drawing assessment, these same students increased their understanding of basic hydrological components and processes, indicated by the inclusion of subsurface components and processes, such as infiltration and groundwater (Figure 4).

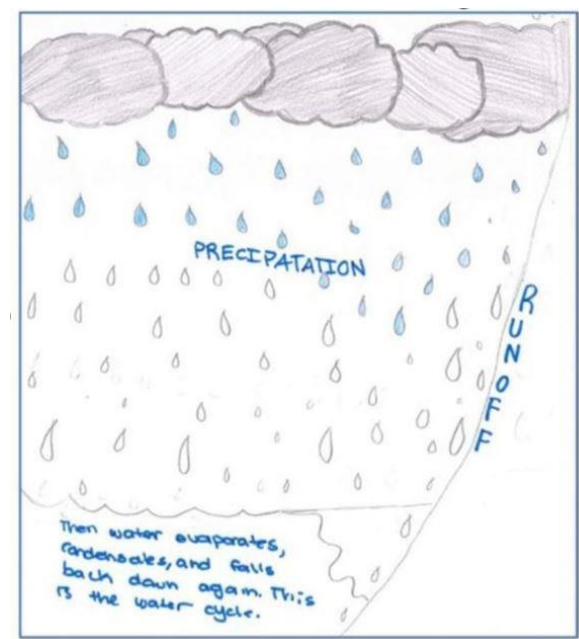

(a) Student 34

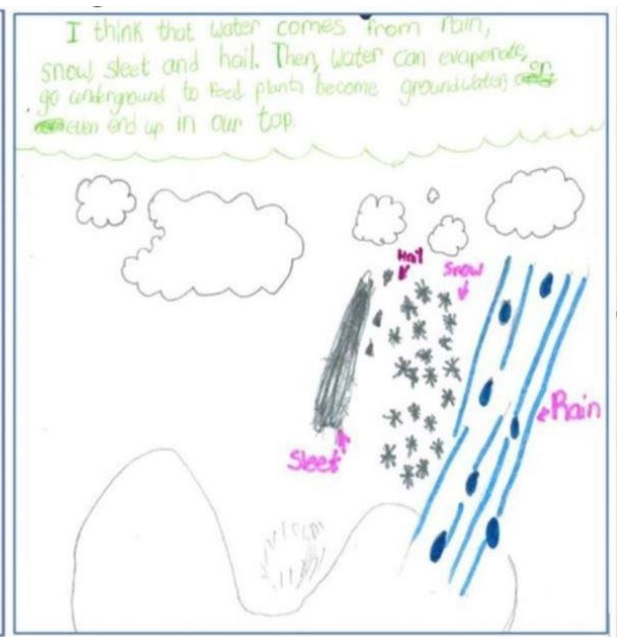

(b) Student-3

Figure 3. Pre-Drawings Assessments from two different study participants, one in class \#1 (a) and the other in class \#2 (b) that highlight only surface and atmospheric interactions. 


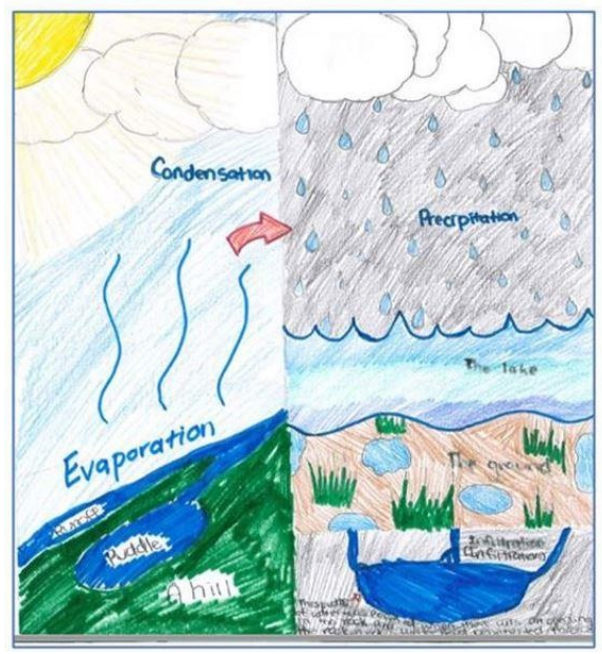

(a) Student 34

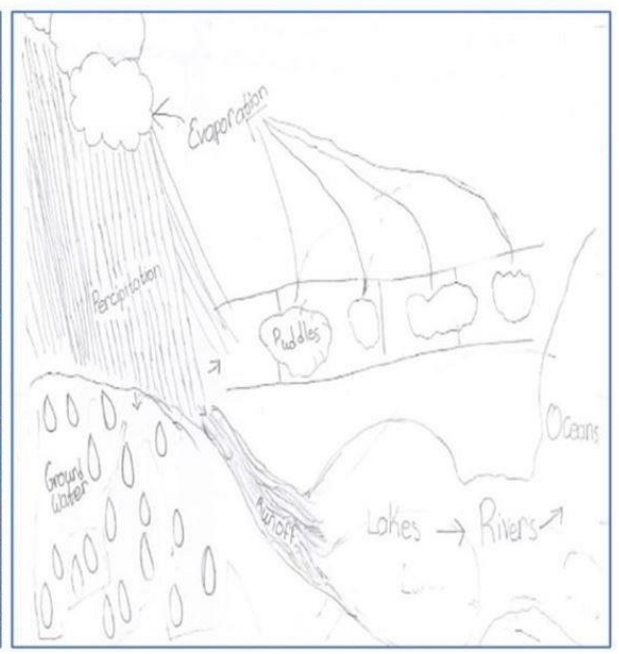

(b) Student-3

Figure 4. Post-Drawing Assessments from two different study participants, one in class \#1 (a) and the other in class \#2 (b) that highlight the inclusion of subsurface interactions.

\subsection{Systems Thinking Skills}

For research question 2, we asked: How does participation in the experiential learning unit facilitate understanding of complex systems in elementary science students? Findings from all research instruments illustrated that some of the students that participated in the experiential water unit were able to foster an understanding of systems and identify relationships between system components. By unifying water cycle components with their processes, students built a more comprehensive understanding of how water flows in nature, as well as in the urban environment as part of the New York City water supply.

Although students from both sections were able to induct structural thinking and generalize about system classes, skills of dynamic and cyclic thinking were most developed in class \#1. Findings from the pre-unit tests indicated that students in class \#1 may have been more familiar with the content, having a higher level of baseline understanding of the subject matter. Both class sections used the same classroom materials and were taught by the same classroom science teacher twice a week. When asked what they were able to learn by building and revising their water filters, several students illustrated the systems thinking ability to identify relationships between systems components:

"By building and revising our water filter we learned about how aquifers can help water get filtered if they have the right porosity." (Student \#23, class \#2, water filter reflection assessment, December 2016).

"When it rains, and it runs through the forest, or in a stream with rocks, the leaves and rocks naturally filter it, like in our models, how the water flowed through the gravel." (Student \#49, class \#1, water filter reflection assessment, December 2016).

"In nature we can see filtering when rainwater infiltrates into the ground like how our water infiltrated into the bottom of our filter." (Student \#26, class \#2, water filter reflection assessment, December 2016).

Moving up the systems thinking hierarchal scale, one student was able to organize system components and processes within a framework of relationships:

"I think it was important to think about the layers and which order each material goes because each material has a special function that they are supposed to do in our water filter." (Student \#38, class\#2, December 2016). 
Other students were able to understand more complex systems thinking skills, such as the cyclic nature of systems and dynamic relationships:

"After landing on the schoolyard, the water would probably either evaporate or find the nearest soil and infiltrate. Then, the water cycle starts all over again." (Student \#6, class \#2, post-test, December 2016).

"The water is first collected and then filtered in a water filter system. Once they ensure the safety of the consumption of these waters, it get[s] put into a distribution system where they distribute our water to the tap." (Student \#29, class \#2, post-test, December 2016).

"First, it will be on the schoolyard downstairs. Then, it will either infiltrate or runoff. If it runs off, then it will end up in the ocean and the cycle will start all over again. However, if it infiltrates, it may do the same or keep going down into the soil. This is the molecules path." (Student \#10, class \#2, post-test, December 2016).

Pre- and post-drawing assessments for both class sections indicated the use of structural thinking, showing simple causal interrelations. From the pre- to post-test, there was a $25 \%$ increase in student identification of system relationships and a $23 \%$ increase in student identification of cyclic perceptions. These findings indicated that students improved their understanding of complex systems thinking components and their ability to understand dynamic relationships in systems that are in constant motion. This was evident in one student's explanation of the water cycle; in that, it is constant and has no beginning or end (Figure 5).

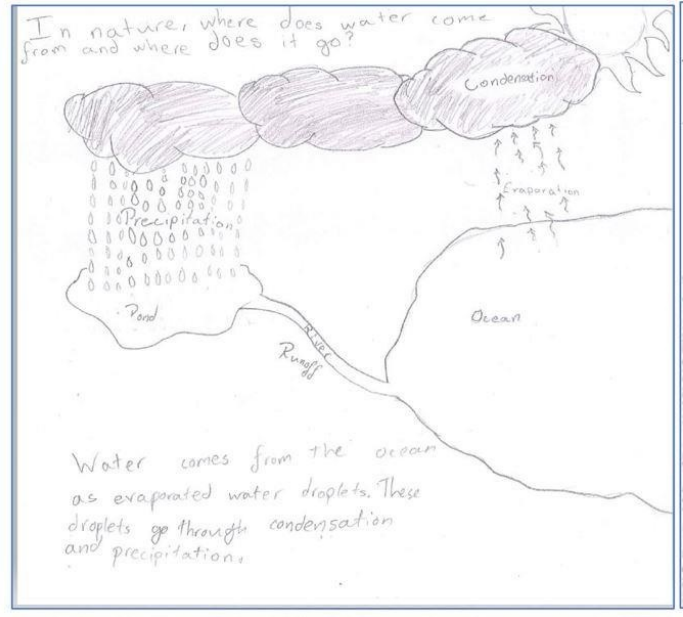

(a) Pre-drawing assessment

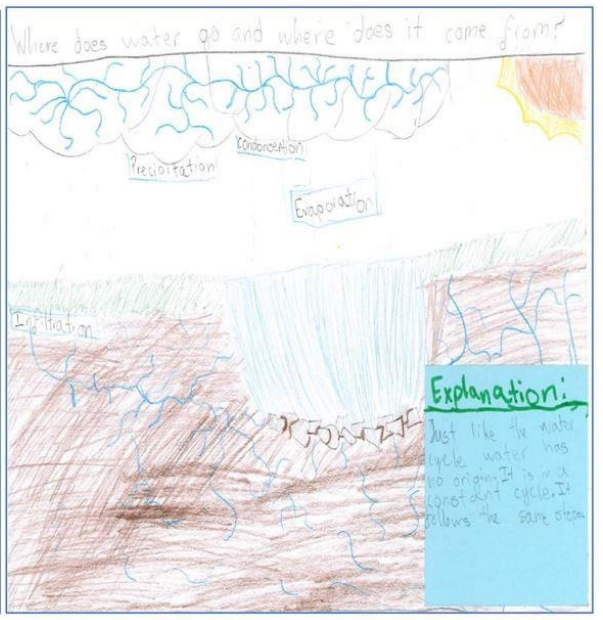

(b) Post drawing assessment

Figure 5. Pre and Post Drawing Assessments from - Student 36, Class \#1 that show the progression from simple structuralthinking (a) to cyclic thinking (b). Explanation on post drawing assessment (b) states: "Just like the water cycle, water has no origin. It is in a constant cycle. It follows the same steps."

Through abstract conceptualization, many students were able to reflect on the logic and practical application in their engineering design practice. In their water reflection assessments, Student \#38 from class \#2 responded in a way that indicated their ability to organize system components and processes within a framework of relationships:

"I think it was important to think about the layers and which order each material goes because each material has a special function that they are supposed to do in our water filter." (Student \#38, class\#2, water filter reflection assessment, December 2016).

Student \#49 from class \#1 also reflected in a way that indicated an understanding of this systems thinking skill: 
"I was able to find out key points in building filters, such as the types of sediments to use, the pouring speed, the pattern, and the layers." (Student \#49, class \#1, water filter reflection assessment December 2016).

Some students were also able to understand the dynamic nature of a water system using the construct of patterns in their water filter design. In our final class discussion, student \#46 and \#49 from class \#1 presented evidence from their filter design efficiency:

"In our last filter we decided to make a pattern in our filter-sand, dirt, gravel, and then kept going and I kind of feel like layers .... because the sand um ... the sand and the color. I feel like the sand changed the color of the water.... and then it went through again and again, and it got cleaner and cleaner." (Student \#46, class \#1, classroom observation, December 2016).

"How fast we were pouring the water, the sediments, and a pattern, because rain it goes across different sediments, and it comes little by little, over patterns." (Student \#49, class \#1, classroom observation, December 2016).

Through each iteration of active experimentation and reflective observation, students demonstrated an ability to generalize about the efficiency of their design to improve water quality by constructing explanations and designing solutions:

"Our conclusion is that the third sample was the most successful because it was the least dirty. We think that the gravel played the most important role because it took all the dirty water and took out the dirt from the water." (Student \#37, class \#1, science notebook, December 2016).

\section{Discussion}

\subsection{Conceptual Understanding}

As a result of the intervention, many students improved their understanding of hydrological concepts of permeability and porosity, condensation, and infiltration. Overall, test scores increased from the pre- to the post-unit tests for more than half of all students in the two classes. Open-ended questions and those that addressed groundwater flow presented the greatest evidence that students had improved their water literacy in their understanding of water cycle processes, from solely surface atmospheric transformations (evaporation, condensation) to include subsurface facets of the cycle (runoff, infiltration, groundwater flow). When viewed through the lens of the experiential learning intervention, these findings support positive learning outcomes in student engagement and conceptual understanding. Furthermore, other researchers have found that experiential learning significantly decreased symptoms of stress, hyperactivity, and impulsivity and increased academic performance [46-48].

One misconception that did not change from the pre- to the post-unit test was a higher-level question (\#16) that asked where groundwater was found. The correct response is that it is only found where there is soil since water cannot move through rock; however, over $75 \%$ of the students chose the incorrect response that groundwater is almost anywhere beneath the Earth's surface. This misconception might indicate that students' conception was that water could move through rock, but this finding was inconsistent with results from other questions on the post-test and statements made from their water filtration models that water moves through the pores between the rocks, not the rocks themselves. Kirschner [49] notes that students do not often have the theoretical knowledge or cognitive ability to see these patterns in the data they are collecting. However, some students in this study were able to use their observations of how layers and patterns evolved in the engineering design of their water filter to approach the problem of making their dirty water sample clean. Crude analysis of the pre- and post-test unit question subject areas also indicated that students were able to comprehend content from higher level sources, such as the 8th grade Regents and undergraduate level testing. DiSessa [50] argues that all knowledge is fragmented and that children hold neither conceptions nor misconceptions of the Earth 
that "pieces of knowledge" are small, self-explanatory, and loosely connected (p. 50). It was through the reorganization of this fragmented knowledge that learning occurred.

Triangulated with the unit tests, the drawing assessments measured students' level of understanding of natural phenomena through their knowledge of surface concepts in the water cycle, as well as gaps in their understanding of subsurface processes and interactions [12,51]. Consistent with findings in the literature, elementary students in this study best understood atmospheric components, such as evaporation and condensation [52-55]. Students' conceptions of groundwater were like those found by Dickerson and Dawkins [8] where they viewed it as a pool, lake, or pipe or static, subsurface lake [55].

Although no statistically significant differences were observed in drawing assessment scores, more than half of the students increased their score from the pre- to the post-drawing assessment. According to Chang [51], children's drawings convey their level of conceptual understanding and illustrate how they conceptualize a science experience. Like Kolb's [27] assertion, learning and knowledge are the byproducts of the transformation of experience. This was evident in the students' drawing assessments, where learning of hydrological concepts and the ability to transfer this understanding to other science domains was most pronounced. This finding is consistent with other researchers that have used draw and explain activities with elementary students to assess conceptual understanding of the hydrological cycle $[1,3]$. Having these drawings in student portfolios also allowed them to self-assess how their prior thinking may or may not have changed throughout the experiential water unit.

One of the formative assessments for class \#1 (pre-unit test) provided evidence that these students had an increased baseline understanding of science concepts than class \#2. This may have been a contributing factor to the significant increase from pre- to post-drawing assessments for class \#1. An interesting finding was that Class \#1 had mathematics with the science teacher five times a week. In classroom observations of the teacher, she used vocabulary like what is found in the NGSS crosscutting concepts of scale, proportion and quantity, patterns, and cause and effect, and many of the science and engineering practices of mathematics and computational thinking. She also utilized terms from mathematics, like ratio, proportion, and rate, to illustrate water properties and processes in the students' engineering models. We cannot speculate on the impact this had on these students, however, their familiarity with the teacher may have influenced the climate of the classroom environment and the level of comfort for students to work more constructively to take on new concepts. Whether she was aware of it or not, the classroom teacher was facilitating the transfer of physical concepts to new problems and settings, which Wiggins and McTighe [56] discuss as one of the fundamental principles of transfer-the ability to apply what one has learned to a different context. Bransford, Brown, and Cocking [57] define transfer as developing competence in an area of inquiry whereby one can organize knowledge in a manner that facilitates retrieval and application. To develop this level of competence, students need the opportunity to foster a deep level of understanding of the subject matter to enable them to transform information into useable knowledge. However, without observation of the students' experiences in mathematics classrooms, the difference in learning outcomes cannot be attributed to this discovery.

Similar to studies that have used aquatic explanatory models with elementary aged students $[20,53,58]$, reflective observation and active experimentation were critical to positive learning outcomes and an essential component in the continuum of the experiential learning model $[27,59]$. By allowing students to continuously reflect, discuss, and write about their observations throughout the experience, they were able to make meaning out of the classroom community they were interacting with. It is this interaction that frames education as a social process, situated in a larger community of exchanging ideas. Here students began to change their conceptions and enact scientific inquiry. The educative value of experiential learning is best defined by Dewey [23] in the context of continuity and interaction, in that each experience creates a ripple effect as they combine each subsequent experience. Through critical reflection, students not only achieve personal growth and 
development, but they also foster a sense of humanity among their peers. It is through this continuous and cumulative progression of experience that students begin to grasp, transform, and make meaning in their world. Kolb's experiential learning model [27] encourages learners to participate in identifying and activating new discoveries, while concurrently exploring scientific processes through the components and context of each experience. This sense of discovery makes experiential learning an appropriate framework for teaching and learning with elementary-aged students. Concrete experiences situated within natural environments were meaningful to students and fostered their water literacy and systems thinking skills. Chawla [60] maintains that experiences in nature are a way for individuals to gain awareness about their environment and acquire knowledge. Values and experiences of nature give individuals the determination to act to solve present and future environmental problems [59].

\subsection{Systems Thinking}

Initial results from both pre-unit tests and pre-drawing assessments indicated that students understood various water processes but did not understand the systematic structure of the water cycle [12]. Most students viewed groundwater as a disconnected system with no relationship to the surrounding land, soil, rocks, or vegetation [1]. Elementary students' conceptions of groundwater are further confounded by their inability to conduct spatial reasoning [31] because they encounter difficulty forming mental models of hidden components that they cannot see with the naked eye $[8,10]$.

The NGSS cross-cutting concept of systems provided an integrating context across several science domains and helped students deepen their understanding of disciplinary core ideas to develop a coherent and scientifically-based view of the world [6]. Through this study, we were able to use explanatory modeling to meaningfully link the science, technology, engineering and math (STEM) disciplines of science and engineering to meet the NGSS performance expectation of understanding of the significant role of the movement of water in the Earth's processes. Student-generated visual representations illustrated the value of non-standard representations in providing a basis for student clarification and a visible and concrete means for teachers and students to monitor progress in their learning [61,62]. The ability of Avenue Schools elementary science students was consistent with findings in the literature, that children of this age can use physical modeling to represent systems to construct explanations and solutions of water filter efficiency and allow them to problem-solve complex concepts using model-based reasoning [63,64]. The definition of science is constructed through these communities of discourse where each member brings their set of experiences and beliefs to the group, and "they create through social interaction particular ways of talking, thinking, acting and interacting" [65] (p. 24). Therefore, the ability to create, use/apply, evaluate, and revise models are necessary skills for acquiring an in-depth understanding of both technological development processes and scientific practices which are also core components for pursuing authentic learning in technology, mathematics, and science classrooms [66]. Socially situated learning acknowledges that our values, experiences, and cultural contexts are inextricably linked to performance outcomes [67]. Learners develop an understanding of the world through the construction and revision of mental models. Mental imagery facilitates memory and representations allow us to form mental models of images and concepts to promote a better understanding of connections between systems and functions in our everyday world [31]. By reflecting on the properties of relations represented in mental models, an individual may come to acquire higher-order knowledge of them [68]. The use of such explanatory models in classroom instruction engages students to participate in scientific reasoning by inventing and revising models of the natural world [20]. Students were actively involved in analyzing their situations, finding solutions, and taking actions to address their concerns and to work for the betterment of other humans [69]. According to Assaraf and Orion [2], students who understand their local environment and the processes taking place therein 
might have better tools to evaluate the changes taking place in it and might know how to live in peace with it.

This study aligns with other studies that have explored the ability of elementary students to understand complex systems. Similar to work with elementary school students done by Assaraf and Orion [2] and Kali, Orion, and Eylon [15], the instructional approach was a key component in developing systems thinking in students. In particular, the use of more than one research setting (classroom and informal field site) and the use of multiple representations of water movement was an integral approach for students to develop systems thinking skills. Research by Evagorou et al. [11] also confirms that when supported by a properly designed learning environment (in the case of a computersimulated environment), elementary students can develop these skills, as well. This current study has refuted the argument that elementary school students do not have the cognitive ability to understand complex systems $[10,31,70,71]$; students in this study were able to comprehend cyclic and dynamic thinking. The development of these systems thinking skills is instrumental for students to understand the systematic structure of the water cycle [1]. Based on these findings, it is recommended that systems thinking be introduced at the elementary school level so that students can begin to develop a continuum of understanding of relationships between Earth components that will develop to a higher level as they progress in school [2,14].

\section{Conclusions}

Learning through experiential methods was meaningful to the students and a valuable framework to facilitate student engagement in NGSS science and engineering practices. Through the development and use of models, students grasped an understanding of systems and systems thinking, which they were able to articulate in their learning outcomes and academic progress. The students in both class sections were able to develop a conceptual understanding of water science and engineering, as well as water in Earth systems, through science discourse and practices [60,72]. Students converted concrete experiences into learning by developing their initial misconceptions about water cycling from the surface and atmospheric to understanding foundational components of hydrology and groundwater [2,27].

\subsection{Implications of Curriculum Development}

In our modification of the EiE unit, Water, Water, Everywhere, water pollution is presented in a local context. The rationale for this change was that elementary students within urban environments, such as New York City, do not always have direct access to the natural environment and that they would not be able to connect with an environment on the other side of the world. Within the subcultures that influence a student's understanding of science - their family, peers, school, media, and the physical, social, and economic environments-all have defining components of norms, beliefs, and values that students construct and negotiate within their realities [73]. By providing field opportunities to experience water and nature through local authentic environments, students were able to connect to the concepts in a meaningful way, and one that impacts their lives. This curriculum and teaching revision was instrumental in transitioning student understanding of water in our world from global to local ecological environments. These adaptations also presented opportunities for students to broaden their view of the different domains of science, that not all science is applied in the same manner, not all scientists do the same kind of work, and that learning science is a dynamic process. This enabled them to develop a real-world understanding of the diverse fields in science by observing the world of environmental ecologists, engineers, and science educators through participation in concrete experiences. 


\subsection{Implications of Assessment}

Wiggins and McTighe [56] argue that understanding can only be developed through multiple methods of ongoing assessment. Throughout this study, the use of multiple assessments and representations of water systems allowed learners to enact the tenets of the experiential learning model and what Dewey [25] defines as authentic assessment, where they were presented with an authentic problem that not only aroused engagement and experimentation but had situational or personal meaning to the learner [56]. Although we found statistical significance between the unit test scores before and after the intervention, the use of closed-ended testing alone does not provide information about student understanding [74]. That is why triangulation of assessments was an important strategy in the scope of this research study. Used in conjunction with other assessment strategies, drawings provided insight into students' conceptual understanding and were a useful tool for educators to document and validate acceptable evidence of student learning, not just a set of content and activities to be covered. The integration of art and science in early childhood is vital in laying a strong academic foundation for curriculum alignment in upper grades and a deeper conceptual understanding and attainment of scientific literacy. Researchers have used drawing tasks as an assessment instrument to investigate water concept misconceptions and to establish a coding framework in the analysis $[2,11,13,17,41]$. The use of student drawings as an assessment strategy is appropriate and flexible for all communities and types of learners [74].

\section{Limitations of Study}

Direct limitations to this study were the time constraints being on-site at the research settings. The first author works full time as a Research Scientist for the City of New York and used personal leave time to participate in science lessons that were part of the research component of the experiential unit. In addition, research instruments that were created to score and code student artifacts were based on a combination of expert knowledge, standards, and real-world experience. In practice, these instruments were used for the first time as part of the analysis and therefore may have had some shortcomings regarding their validity and reliability due to their lack of application. These research instruments were also administered by the classroom science teacher and not the researchers, so it was not clear if the teacher provided instructions or gave students access to their existing artifacts to assist in this assignment. Another limiting factor of this study was that the population being studied might not have been representative of other 6th-grade science students. These students were at a gifted and talented school as opposed to a district school, and they may have had a baseline understanding of some of the science concepts taught in the unit.

\subsection{Further Research}

Based on the findings from this study, elementary students can understand systems thinking concepts about water cycles and systems. Further research in this area would reinforce this finding. To facilitate this, the use of multiple assessments, such as unit tests, questioning, and drawing tests, would confirm that students have a deep understanding of system components, processes, and relationships between them. Water system assessments that have traditionally been used in upper-level elementary science, such as knowledge integration activities and concept maps $[1,16]$, should also be considered to further the breadth and depth of scientific knowledge.

Author Contributions: Conceptualization, A.R.L. and F.M.M.; methodology, A.R.L. and F.M.M.; software, A.R.L.; validation, A.R.L.; formal analysis, A.R.L.; investigation, A.R.L.; resources, A.R.L.; data curation, A.R.L.; writing-original draft preparation, A.R.L.; writing-review and editing, A.R.L. and F.M.M.; visualization A.R.L.; supervision, F.M.M.; project administration, F.M.M.; funding acquisition, F.M.M. All authors have read and agreed to the published version of the manuscript.

Funding: This research received no external funding. 
Institutional Review Board Statement: The study was conducted according to the guidelines of the Declaration of Helsinki and approved by the Institutional Review Board of TEACHERS COLLEGE, COLUMBIA UNIVERSITY (protocol code 16-361, 6/14/2016).

Informed Consent Statement: Informed consent was obtained from all subjects involved in the study.

Data Availability Statement: The data presented in this study are available on request from the corresponding author. The data are not publicly available due to privacy of participants.

Acknowledgments: Thank you to Vanessa DeFerrari, Noreen Gallagher, Bianca Hernandez, Joshua Lefkowitz, and Rodolfo Perez for scoring drawing assessments and providing moral support.

Conflicts of Interest: The authors declare no conflict of interest.

\section{Appendix A}

Table A1. Avenue School Unit Plan, Page 1.

\begin{tabular}{|c|c|c|}
\hline $\begin{array}{l}\text { Grade \& Subject } \\
\text { 6th Grade Science } \\
2016-2017\end{array}$ & 1. & $\begin{array}{l}\text { Lesson Format (Check all that apply) } \\
\square \text { Workshop Model } \\
\text { X Inquiry-Based Learning }\end{array}$ \\
\hline Unit Title: Watersheds and & Quality & $\begin{array}{l}\text { Dates of Instruction ( } 30 \text { of sessions) } \\
10 \text { Weeks }\end{array}$ \\
\hline Unit Overview & $\begin{array}{l}\text { This is } \\
\text { engage } \\
\text { their c } \\
\text { waters } \\
\text { Elemer }\end{array}$ & $\begin{array}{l}\text { science. The goal of this course is for students to } \\
\text { experience to be able to synthesize meaning out of } \\
\text {, and collaborate. In this unit, we will focus on } \\
\text { ns. This unit is a blend of the Engineering is } \\
\text { nit and original water lessons. }\end{array}$ \\
\hline Essential Questions & $\begin{array}{l}\text { What } 1 \\
\text { How c } \\
\text { How d } \\
\text { Where } \\
\text { What i } \\
\text { What i } \\
\text { How h } \\
\text { How is } \\
\text { How c } \\
\text { What a }\end{array}$ & $\begin{array}{l}\text { ents? } \\
\text { ur schoolyard? } \\
\text { shed? }\end{array}$ \\
\hline Standards & $\begin{array}{l}\text { NYS P } \\
\text { S1.1: F } \\
\text { search } \\
\text { S1.2: C } \\
\text { prelim } \\
\text { S1.3: R } \\
\text { that th } \\
\text { S1. 4: } \subseteq \\
\text { presen } \\
\text { S2.1: U } \\
\text { S3.1: D } \\
\text { and cr } \\
\text { T1.1: Ic } \\
\text { of gen } \\
\text { 1.1: Us } \\
\text { create }\end{array}$ & $\begin{array}{l}\text { iith the aid of references appropriate for guiding the } \\
\text { ations. } \\
\text { for natural phenomena, especially by proposing } \\
\text { proposed explanation of everyday observations so } \\
\text { oy others. } \\
\text { d to reconcile with their own thinking the ideas } \\
\text { ers, authors and scientists. } \\
\text { se of their own design for further observations. } \\
\text { er representations of observations in conventional } \\
\text { eir research question or hypothesis. } \\
\text { echnical solutions from an investigation of situations } \\
\text { to integrate several forms of information in order to } \\
\text { ind text-based presentations. }\end{array}$ \\
\hline
\end{tabular}


Table A1. Cont.

\begin{tabular}{|c|c|c|}
\hline $\begin{array}{l}\text { Grade \& Subject } \\
\text { 6th Grade Science } \\
\text { 2016-2017 }\end{array}$ & & $\begin{array}{l}\text { Lesson Format (Check all that apply) } \\
\square \text { Workshop Model } \\
\text { X Inquiry-Based Learning }\end{array}$ \\
\hline Unit Title: Watersheds and $\mathrm{h}$ & Quality & $\begin{array}{l}\text { Dates of Instruction (30 of sessions) } \\
10 \text { Weeks }\end{array}$ \\
\hline Knowledge \& Skills & $\begin{array}{l}\text { Studen } \\
\text { develo } \\
\text { NYC n } \\
\text { The hy } \\
\text { Man-n } \\
\text { Green } \\
\text { Variou }\end{array}$ & $\begin{array}{l}\text { and how the water cycle is impeded by human } \\
\text { t water quality by sampling water from various } \\
\text { the planet. } \\
\text { the damage to the water cycle. } \\
\text { ist. }\end{array}$ \\
\hline Unit Task & $\begin{array}{l}\text { Weekly } \\
\text { Indepe } \\
\text { Lab Re } \\
\text { On De } \\
\text { Reflect } \\
\text { Studen }\end{array}$ & $\begin{array}{l}\text { eflections graded with standard rubric } \\
\text { activities to independent research on essential topics. }\end{array}$ \\
\hline Teamwork & $\begin{array}{l}\text { Triad } 1 \\
\text { Triad } r \\
\text { Expect }\end{array}$ & $\begin{array}{l}\text { green engineering } \\
\text { bute to work product. }\end{array}$ \\
\hline Scaffolds and Extensions & $\begin{array}{l}\text { Divers } \\
\text { Modifi } \\
\text { Video } \\
\text { Extens } \\
\text { Open } \\
\text { Extens } \\
\text { Teams }\end{array}$ & $\begin{array}{l}\text { step by step instructions and visual models. } \\
\text { ions. } \\
\text { al resources or testing student generated hypotheses. } \\
\text { t each other. }\end{array}$ \\
\hline Texts and Resources & $\begin{array}{l}\text { Texts: } \\
\text { Surviv } \\
\text { manuf } \\
\text { Techno } \\
\text { Other }\end{array}$ & $\begin{array}{l}\text { EPA Report, how we use Water, Water from Air, } \\
\text { ePA, report, California Drought, why can't we } \\
\text { omputers at home for homework } \\
\text { ed materials from FOSS kits, video clips. }\end{array}$ \\
\hline
\end{tabular}

Table A2. Learning Objective and Unit Question Schedule.

\begin{tabular}{|c|c|c|}
\hline \multicolumn{3}{|c|}{ Lesson Objectives \& Inquiry Question Schedule } \\
\hline Unit \#1 & & Unit Title: Watersheds and Water Quality \\
\hline \multicolumn{2}{|l|}{ Subject: Science } & Dates and Duration: Fall Semester \\
\hline Lesson & Learning Objective & Student Work \\
\hline 1 & $\begin{array}{l}\text { Qualities of Healthy Water } \\
\text { Teamwork protocol practice }\end{array}$ & $\begin{array}{l}\text { Pretest } \\
\text { Group created rubrics } \\
\text { Reflection and score sheets }\end{array}$ \\
\hline $2 \& 3$ & $\begin{array}{l}\text { Abiotic Factors } \\
\text { LAB: Water Testing } \\
\text { Create master data chart of abiotic factors }\end{array}$ & $\begin{array}{l}\text { Readings followed by initial testing of tap water } \\
\text { and then test samples from lesson. } \\
\text { Add data from abiotic factors to chart } \\
\text { Abiotic factor presentations from each group }\end{array}$ \\
\hline $4 \& 5$ & $\begin{array}{l}\text { Modeling a Watershed } \\
\text { LAB: What is a Watershed? } \\
\text { Sculpting watersheds and basins. Model } \\
\text { contamination. } \\
\text { Content: Where do we find water? } \\
\text { Introduction to the hydrosphere? } \\
\text { HW: How do we use water content map }\end{array}$ & $\begin{array}{l}\text { Pre-Drawing Assessment } \\
\text { Notes on water cycle } \\
\text { Diagram and reflection questions }\end{array}$ \\
\hline 6 & $\begin{array}{l}\text { Stream Erosion and Topography } \\
\text { LAB: Mapping the Bronx River } \\
\text { Structured inquiry } \\
\text { Prepare for NYBG trip, talk about } \\
\text { wetlands, streams, topography } \\
\text { Create a class hypothesis }\end{array}$ & $\begin{array}{l}\text { Topography kit } \\
2 \text { student worksheets } \\
\text { Independent reflection }\end{array}$ \\
\hline
\end{tabular}


Table A2. Cont.

\begin{tabular}{|c|c|c|}
\hline \multicolumn{3}{|c|}{ Lesson Objectives \& Inquiry Question Schedule } \\
\hline \multicolumn{2}{|c|}{ Unit \#1 } & Unit Title: Watersheds and Water Quality \\
\hline \multicolumn{2}{|l|}{ Subject: Science } & Dates and Duration: Fall Semester \\
\hline Lesson & Learning Objective & Student Work \\
\hline 7 & $\begin{array}{l}\text { Field Trip: New York Botanical Garden } \\
\text { Practice making a hypothesis using } \\
\text { background information on abiotic factors }\end{array}$ & Sampling at various sites in garden (groups) \\
\hline 8 & $\begin{array}{l}\text { Our Water System } \\
\text { History of NYC Water Supply, drinking } \\
\text { and sewage }\end{array}$ & Identifying solutions and problems \\
\hline 9 & $\begin{array}{l}\text { Hudson River Snapshot Day } \\
\text { LAB: Field Sampling at Hallett's Cove } \\
\text { Compare to Bronx River } \\
\text { Introduce Fecal Coliform }\end{array}$ & $\begin{array}{l}\text { Debriefing trip and writing discussion } \\
\text { Science notebooks }\end{array}$ \\
\hline 10 & $\begin{array}{l}\text { LAB: Field sampling on the Bronx River } \\
\text { Rocking the Boat }\end{array}$ & $\begin{array}{l}\text { Sampling different abiotic factors at different } \\
\text { stations }\end{array}$ \\
\hline 11 & $\begin{array}{l}\text { Using Field Data } \\
\text { Field Hypothesis }\end{array}$ & Science notebook \\
\hline 12 & Combined sewer overflow data & Science notebook \\
\hline 13 & Field Work hypothesis & Science notebook \\
\hline 14 & Revising your claim & Science notebook reflection \\
\hline 15 & Lab Report & Individual lab report data worksheet \\
\hline 16 & $\begin{array}{l}\text { Permeability Explore } \\
\text { Introduce isolating a variable, controls, etc. }\end{array}$ & Review vocabulary sheet \\
\hline 17 & $\begin{array}{l}\text { LAB: Engineering- Water Filters } 1 \\
\text { Conduct as a controlled lab }\end{array}$ & Science notebook \\
\hline $18 \& 19$ & $\begin{array}{l}\text { LAB: Engineering Water Filters } 2 \& 3 \\
\text { Guide through lab work }\end{array}$ & Design and re-design water filters \\
\hline 20 & $\begin{array}{l}\text { Debriefing } \\
\text { Experimental Design and Reflection } \\
\text { Data Analysis }\end{array}$ & Water filter assessment \\
\hline 21 & $\begin{array}{l}\text { LAB: Mapping and runoff zones } \\
\text { Where can water runoff when it rains at our } \\
\text { school? } \\
\text { Students tour grounds and diagram findings }\end{array}$ & $\begin{array}{l}\text { Scaled maps of schoolyards with drainage and } \\
\text { materials marked }\end{array}$ \\
\hline 22 & $\begin{array}{l}\text { Content: Green engineering for runoff control } \\
\text { How can urban engineers plan for runoff in the } \\
\text { city environment? }\end{array}$ & $\begin{array}{l}\text { Compare cost and effectiveness of green measures } \\
\text { Post Drawing Assessment }\end{array}$ \\
\hline 23 & $\begin{array}{l}\text { LAB: Model Making- creating bioswales } \\
\text { Importance of models in science }\end{array}$ & Posttest \\
\hline 24 & Green infrastructure project (multiple days) & \\
\hline 25 & Share Fair projects & \\
\hline 26 & $\begin{array}{l}\text { Assessment } \\
\text { Experimental design and reflection } \\
\text { using literature. }\end{array}$ & \\
\hline
\end{tabular}

\section{Appendix B}

Sediments and Permeability

Water Filter Reflection

In class we explored the properties of sand, soil and gravel. What do these materials have in common? What is different?

Where do we see filtering in nature?

\section{Designing a Water Filter}

What was important in thinking about how to design your water filter?

How is your filter design similar/different to how a water system works?

What were you able to learn by building and revising your own water filter? 


\section{Appendix C}

Student Pre/Posttest Unit questions 1-9

1) Sleet, rain, snow, and hail are forms of ${ }_{(3)}$ :

a) Erosion

b) evaporation

c) groundwater

d) precipitation

2) Earth's hydrosphere is a layer of $(1)$

a) rock

b) air

c) lava

d) water

3) A soil sample contains living \& nonliving materials. Which material was once living? (2)

a) sand particles

b) decomposing leaves

c) small pebbles

d) water droplets

4) Why does water move very slowly downward through clay soil (5) ? $^{\text {? }}$

a) Clay soil is composed of low-density minerals.

b) Clay soil is composed of very hard pieces of matter.

c) Clay soil has large pore spaces between pieces of matter.

d) Clay soil has very small pieces of matter.

5) Name places where you would find water in the world $(9)$.

6) Water is boiled in a pan on a stove. The state of matter of the water changes from $(2)$ :

a) liquid to solid

b) solid to liquid

c) gas to liquid

d) liquid to gas

7) Which is most important in determining the amount of groundwater that can be stored within a rock $(5)$ ?

a) the rock's geologic age

b) the rock's hardness

c) the rock's porosity

d) the rock's color

8) Describe the path a molecule of water might follow through the water cycle starting from rain as it lands on the schoolyard downstairs (9).

9) Which of the following BEST describes the water cycle? 
Student Pre/Posttest unit questions 10-15.

a) Collection Evaporation Precipitation Condensation

b) Condensation Evaporation Precipitation Collection

c) Precipitation Collection Evaporation Condensation

d) Evaporation Precipitation Collection Condensation

10) When it rains, water will runoff the surface of the ground if the soil is (5):

a) highly permeable

b) steeply sloped

c) covered with trees

d) loose and sandy

11) On a hot and sunny day, a boy poured a glass of cold water. A few minutes later, the glass was wet and slippery on the outside. How did the water get there $(7)$ ?

a) It rained.

b) It condensed.

c) It evaporated.

d) It leaked through the glass

12) The four major systems of the Earth are the geosphere, hydrosphere, atmosphere, and biosphere. Describe each of these major systems ${ }^{(9)}$.

13) What is groundwater $(8)$ ?

a) Liquid water that resides beneath the Earth's surface.

b) Muddy mixture of water and dirt that lies beneath the Earth's surface.

c) Only the water found in underground lakes and rivers that is clean enough to drink.

d) Only water that is moving beneath the Earth's surface.

14) Why is it important to stop pollution of the soil (7)?

a) Animals that live in the soil might die.

b) Humans eat plants that have grown in the soil.

c) When water flows through polluted soil it might become polluted.

d) All of the above are reasons why it is important to stop pollution of soil.

15) The diagram below shows a potato plant in a cup. The cup was originally filled to the top with water. Explain why the cup no longer contains water (2)

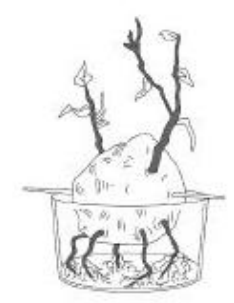


Student Pre/Posttest unit questions 16-18

16) Where is groundwater found $(8)$ ?

(a) Only in wet climates.

(b) Only where there is soil since water cannot move through rock.

(c) Groundwater can exist in rock or soil but will not be found beneath the Earth's surface.

(d) Almost anywhere beneath the Earth's surface.

View the object below to answer questions 17 and 18

A girl has designed a water filter using a metal window screen. She wants to clean brown water with lots of small pieces of dirt floating in it. She pours the dirty water through the metal screen, but it does not change (7)

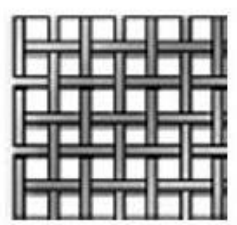

17)What would be the BEST thing she could do to remove the small pieces of dirt?
a) Scoop out the particles with a spoon.
b) Use a filter material with larger holes.
c) Use a filter material with smaller holes.
d) It is not possible to remove the small pieces of dirt.

18) What would be the BEST thing she could do to remove the brown color?
a) Clean the water with soap.
b) Use a filter material that is softer.
c) Use a filter material with smaller holes.
d) It is not possible to remove the brown color.

Student Pre/Posttest unit questions 19-20

19) Five processes in the water cycle are labeled in the diagram below. (4)

\section{Water Cycle}

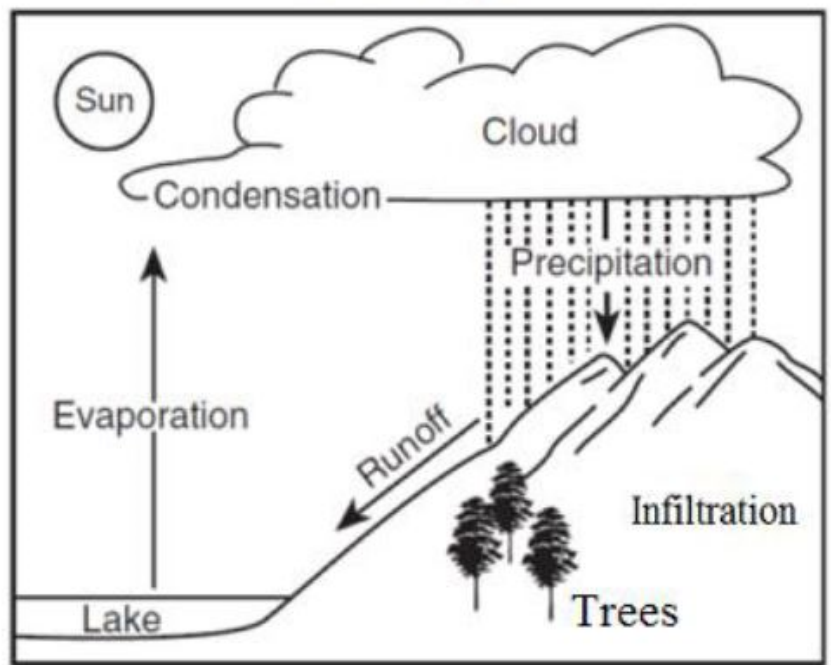

The first column of the chart below describes what happens during each process in the water cycle. Complete the chart by filling in the word for each process. An example is shown for the process in the first row. 


\begin{tabular}{|c|c|}
\hline What Happens During the Process & Water Cycle Process \\
\hline Water falls from the cloud to the ground. & Precipitation \\
\hline Liquid water flows over Earth's surface. & \\
\hline Liquid water changes into water vapor. & \\
\hline Water vapor changes into liquid water. & \\
\hline $\begin{array}{c}\text { Liquid water that flows over the Earth's } \\
\text { surface that percolates through the soil and into pores } \\
\text { and hollows of permeable rocks. }\end{array}$ & \\
\hline
\end{tabular}

20) Please mark next to the statement whether you think it is TRUE (T) or FALSE $(F)_{(6,8)}$

(1) Most of the underground water persists in the small pores of the rock, similarly to a well-watered sponge.

Student Pre/Posttest unit questions 20, 21/Posttest questions 17-19

(2) Underground water is similar to underground lakes that are located in spaces inside the soil.

(3) Rocks don't influence the composition of water that penetrates them.

(4) Ground water can be found only in raining areas

(5) Clouds are the starting point of the water cycle and the tap at home is the end point.

(6) If the population on earth will continue to grow, water consumption will increase, thus decreasing the amount of water on earth

(7) Ocean is the starting point of the water cycle and groundwater is the end point.

(8) Water on the earth exists in different phases and moves between the atmosphere, underground, land, and oceans.

(9) Human consumption of water is quickly decreasing the amount of water on earth

(10) Global warming is causing a decrease in all water on the earth.

21) Explain how water gets to your tap

\section{Post test}

(Posttest contains ALL the same questions with the addition of the last one below and- exchange these below for 17 and 18 on the pre-test)

17) Two students make a water filter. A diagram of their filter is shown below. They pour murky brown water with leaves in it into the top of their filter. The leaves don't come through, but the water that comes out is still brown. What is the MOST LIKELY problem?

a) Only chemicals can remove color from water.

b) A filter can NOT change the color of the water.

c) The filter is not catching things that are very tiny.

d) The sand in the filter is turning the water brown again.

18) What can the students do to help get the brown color out of the water?

a) Add soap to the water.

b) Add more sand to the filter.

c) Remove the sand from the filter.

d) The students cannot get the brown color out of the water.

19) The students try adding more of each of the materials to their filter. A diagram of their new filter is shown to the right. They pour dirty water into the top of their filter. The water fills up the top of the filter and comes out the bottom too slowly. What is MOST LIKELY the problem? 


\section{Posttest diagram and references}

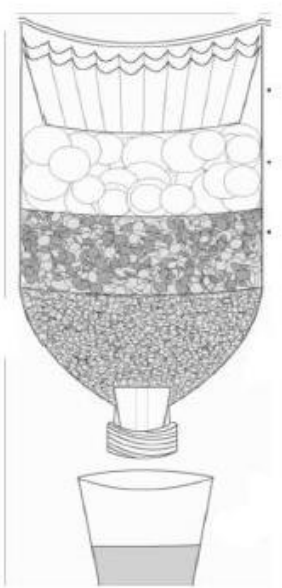

a) Too much sand is blocking the water

b) Too many screens are blocking the water.

c) Too much paper is soaking up all of the water.

d) Too much cotton is soaking up all of the water.

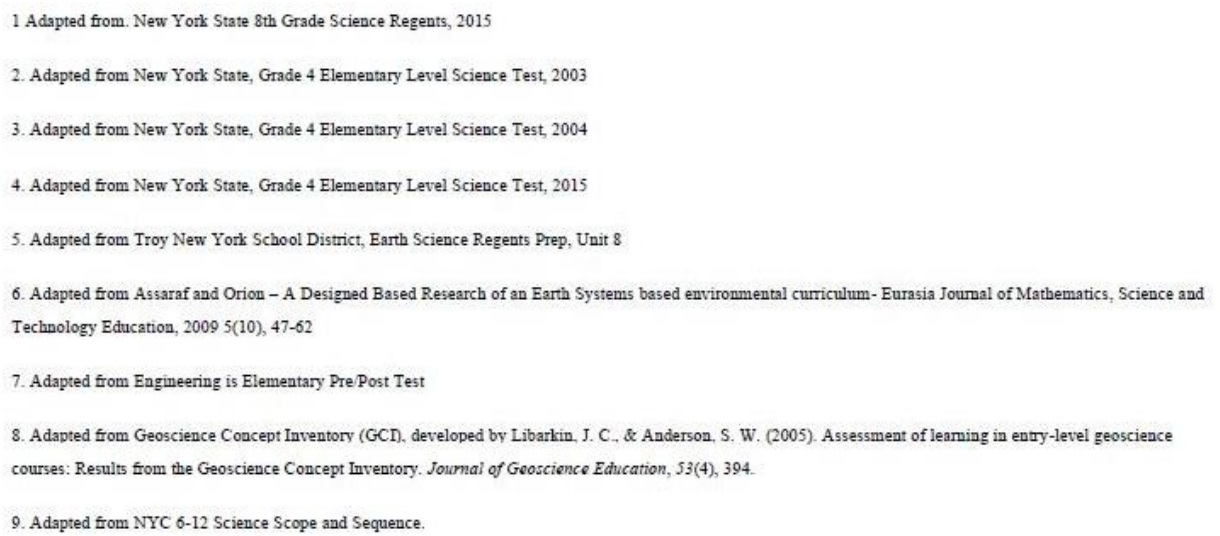

\section{Appendix D}

\section{Systems Thinking Coding Scale}

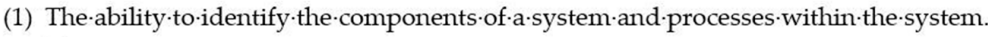

(2) The-ability·to·identify·relationships-among the-systems·components.

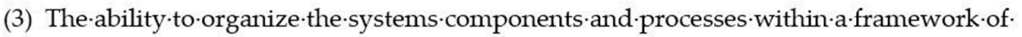
relationships.

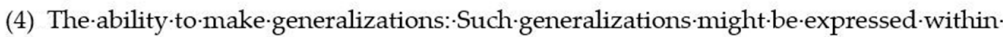
the-hydro-cycle-systems-by-the-understanding that this-system-is-dynamic-and-cyclic.

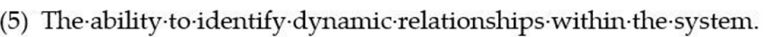

(6) Understanding hidden-dimensions-of the-system.

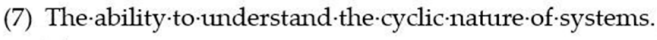

(8) Thinking temporally:-retrospection and prediction. 


\section{Appendix E}

Table A3. Drawing Assessment Rubric.

\begin{tabular}{|c|c|}
\hline Water Cycle Component & Point Value \\
\hline Plant & 0 \\
\hline Human & 0 \\
\hline Animal & 0 \\
\hline Ocean & 1 \\
\hline River & 1 \\
\hline Rock & 2 \\
\hline Soil & 2 \\
\hline Glacier & 3 \\
\hline Spring & 3 \\
\hline Groundwater & 3 \\
\hline Water Cycle Processes & Point Value \\
\hline Clouds & 0 \\
\hline Rain & 0 \\
\hline Sun & 0 \\
\hline Melting & 0 \\
\hline Evaporation & 1 \\
\hline Surface Flow / Runoff & 1 \\
\hline Condensation & 1 \\
\hline Penetration & 2 \\
\hline Underground flow & 2 \\
\hline $\begin{array}{l}\text { Dissolution (identifies transformation from gas to liquid, } \\
\text { solid to liquid) }\end{array}$ & 3 \\
\hline Transpiration & 3 \\
\hline Infiltration & 3 \\
\hline Capillarity & 3 \\
\hline System Relationships & Point Value \\
\hline $\begin{array}{c}\text { Structural Thinking } \\
\text { Simple causal relationships } \\
\text { (i.e.: atmospheric- evaporation, condensation) }\end{array}$ & 1 \\
\hline $\begin{array}{l}\text { Identifying stocks and flows (runoff, infiltration, } \\
\text { transpiration) }\end{array}$ & 2 \\
\hline $\begin{array}{l}\text { Detailed flow structures this is rare (any mathematical } \\
\text { annotations or measurements) }\end{array}$ & 3 \\
\hline \multirow[t]{2}{*}{$\begin{array}{l}\text { Dynamic Thinking } \\
\text { Able to identify that water cycle is continuous, no beginning } \\
\text { or end. }\end{array}$} & \\
\hline & 2 \\
\hline $\begin{array}{l}\text { Generic Thinking } \\
\text { Causal loops (able to identify how variables in system are } \\
\text { interrelated- i.e.,: atmospheric- evaporation, condensation) }\end{array}$ & 1 \\
\hline $\begin{array}{l}\text { Recognizing and using stock-and-flow generic structures } \\
\text { (runoff, infiltration, transpiration) }\end{array}$ & 2 \\
\hline
\end{tabular}


Table A3. Cont.

\begin{tabular}{cc}
\hline Cyclic perceptions & Point Value \\
\hline Atmospheric cycle & 0 \\
\hline Connection via rain on the land & 1 \\
\hline $\begin{array}{c}\text { Connection via rivers from land to sea } \\
\text { transpiration }\end{array}$ & 2 \\
\hline
\end{tabular}

\section{References}

1. Ben-zvi-Assarf, O.; Orion, N. A Study of Junior High Students' Perceptions of the Water Cycle. J. Geosci. Educ. 2005, 53, 366-373. [CrossRef]

2. Assaraf, O.B.-Z.; Orion, N. Development of system thinking skills in the context of earth system education. J. Res. Sci. Teach. 2005, 42, 518-560. [CrossRef]

3. Assaraf, O.B.-Z.; Orion, N. System thinking skills at the elementary school level. J. Res. Sci. Teach. 2010, 47, 540-563. [CrossRef]

4. Ben-Zvi Assaraf, O.; Eshach, H.; Orion, N.; Alamour, Y. Cultural differences and students' spontaneous models of the water cycle: A case study of Jewish and Bedouin children in Israel. Cult. Stud. Sci. Educ. 2012, 7, 451-477. [CrossRef]

5. New York State Department of Education. New York State P-12 Science Learning Standards; New York State Department of Education: Albany, NY, USA, 2016.

6. NGSS Lead States. Next Generation Science Standards; Achieve, Inc. behalf twenty-six states partners that Collab; National Academies Press: Washington, DC, USA, 2013; ISBN 978-0-309-27227-8.

7. Singer, J.; Marx, R.W.; Krajcik, J.; Clay Chambers, J. Constructing Extended Inquiry Projects: Curriculum Materials for Science Education Reform. Educ. Psychol. 2000, 35, 165-178. [CrossRef]

8. Dickerson, D.; Dawkins, K. Eighth Grade Students' Understandings of Groundwater. J. Geosci. Educ. 2004, 52, 178-181. [CrossRef]

9. Reinfried, S. Conceptual Change in Physical Geography and Environmental Sciences through Mental Model Building: The Example of Groundwater. Int. Res. Geogr. Environ. Educ. 2006, 15, 41-61. [CrossRef]

10. Grotzer, T.A.; Basca, B.B. How does grasping the underlying causal structures of ecosystems impact students' understanding? J. Biol. Educ. 2003, 38, 16-29. [CrossRef]

11. Evagorou, M.; Korfiatis, K.; Nicolaou, C.; Constantinou, C. An Investigation of the Potential of Interactive Simulations for Developing System Thinking Skills in Elementary School: A case study with fifth-graders and sixth-graders. Int. J. Sci. Educ. 2009, 31, 655-674. [CrossRef]

12. Cardak, O. Science Students' Misconceptions of the Water Cycle According to their Drawings. J. Appl. Sci. 2009, 9, 865-873. [CrossRef]

13. Draper, F. A proposed sequence for developing systems thinking in a grades 4-12 curriculum. Syst. Dyn. Rev. 1993, 9, 207-214. [CrossRef]

14. Hmelo-Silver, C.E.; Marathe, S.; Liu, L. Fish Swim, Rocks Sit, and Lungs Breathe: Expert-Novice Understanding of Complex Systems. J. Learn. Sci. 2007, 16, 307-331. [CrossRef]

15. Kali, Y.; Orion, N.; Eylon, B.-S. Effect of knowledge integration activities on students' perception of the earth's crust as a cyclic system. J. Res. Sci. Teach. 2003, 40, 545-565. [CrossRef]

16. Shepardson, D.P.; Wee, B.; Priddy, M.; Schellenberger, L.; Harbor, J. What is a watershed? Implications of student conceptions for environmental science education and the National Science Education Standards. Sci. Educ. 2007, 91, 554-578. [CrossRef]

17. Covitt, B.A.; Gunckel, K.L.; Anderson, C.W. Students' Developing Understanding of Water in Environmental Systems. J. Environ. Educ. 2009, 40, 37-51. [CrossRef]

18. Dove, J.E.; Everett, L.A.; Preece, P.F.W. Exploring a hydrological concept through children's drawings. Int. J. Sci. Educ. 1999, 21, 485-497. [CrossRef]

19. Dickerson, D.; Callahan, T.J.; Van Sickle, M.; Hay, G. Students' Conceptions of Scale Regarding Groundwater. J. Geosci. Educ. 2005, 53, 374-380. [CrossRef]

20. Lehrer, R.; Schauble, L. Cultivating Model-Based Reasoning in Science Education. In The Cambridge Handbook of the Learning Sciences; Cambridge University Press: Cambridge, UK, 2005; pp. 371-388.

21. Dewey, J. Summary for Policymakers. In Climate Change 2013-The Physical Science Basis; Intergovernmental Panel on Climate Change, Ed.; Cambridge University Press: Cambridge, UK, 1938; Volume 50, pp. 1-30. ISBN 0684838281.

22. Joplin, L. On Defining Experiential Education. J. Exp. Educ. 1981, 4, 17-20. [CrossRef]

23. Moore, G.T.; Piaget, J. Science of Education and the Psychology of the Child. J. Archit. Educ. 1971, 25, 113. [CrossRef]

24. Roberts, J. Disney, Dewey, and the Death of Experience in Education. Educ. Cult. 2005, 21, 12-30.

25. Dewey, J. Experience and Education. Educ. Forum 1986, 50, 241-252. [CrossRef]

26. Maloof, J. Experience This! The Experiential Approach to Teaching Environmental Issues. Appl. Environ. Educ. Commun. 2006, 5, 193-197. [CrossRef] 
27. Kolb, D.A. Experiential Learning-Experience as the Source of Learning and Development (2nd Edition). Englewood Cliffs, NJ: Prentice Hall, 2015. Available online: https://www.researchgate.net/publication/235701029_Experiential_Learning_Experience_ As_The_Source_Of_Learning_And_Development (accessed on 27 December 2020).

28. Koutsoukos, M.; Fragoulis, I.; Valkanos, E. Connection of environmental education with application of experiential teaching methods: A case study from Greece. Int. Educ. Stud. 2015, 8, 23-28.

29. Cobern, W.W.; Loving, C.C. Defining 'science' in a multicultural world: Implications for science education. Sci. Educ. 2001, 85, 50-67. [CrossRef]

30. Senge, P.M. The Fifth Discipline: The Art and Practice of the Learning Organization [Kindle Paperwhite Edition]; Currency: New York, NY, USA, 2006; ISBN 0385517254.

31. Kuhn, D. Children and adults as intuitive scientists. Psychol. Rev. 1989, 96, 674-689. [CrossRef]

32. New York City Department of Education. Science Scope E Sequence 2015-2016; New York City Department of Education: New York, NY, USA, 2015.

33. Lachapelle, C.P.; Cunningham, C. Engineering is Elementary: Children's Changing Understandings of Science and Engineering. Eng. Educ. 2007. Available online: https://www.researchgate.net/profile/Christine_Cunningham2/publication/252763733_ Engineering_is_Elementary_Children $\backslash \mathrm{T} 1 \backslash$ textquoterights_Changing_Understandings_of_Science_and_Engineering/links/54 58ea860cf2bccc4912ad96.pdf (accessed on 12 December 2020).

34. Dashoush, N. Establishing a Community of Practice between an Elementary Educator and a Scientist as a Means of Professional Development; Columbia University: Columbia, NY, USA, 2015.

35. Levy, A. Investigating the Experience of Water: A Case Study of Teaching and Learning in Elementary School Science; Columbia University: Columbia, NY, USA, 2018.

36. Hudson River Snapshot Day. Available online: https://www.ldeo.columbia.edu/edu/k12/snapshotday/ (accessed on 12 December 2020).

37. Akkus, M. The Common Core State Standards for Mathematics. Int. J. Res. Educ. Sci. 2015, 2, 49. [CrossRef]

38. McMillan, J.; Schumacher, S. Research in Education Evidence-Based Inquiry; Pearson: London, UK, 2014 ; ISBN 9781292022673.

39. Creswell, J.W.; Plano Clark, V.L. Designing and Conducting Mixed Methods Research; SAGE Publications Ltd.: Thousand Oaks, CA, USA, 2017; ISBN 9781483344379.

40. Merriam, S.B. Qualitative Research and Case Study Applications in Education; Jossey-Bass Publishers: San Francisco, CA, USA, 1998; ISBN 0787910090.

41. Rennie, L.J.; Jarvis, T. Children's choice of drawings to communicate their ideas about technology. Res. Sci. Educ. 1995, 25, 239-252. [CrossRef]

42. Landis, J.R.; Koch, G.G. The Measurement of Observer Agreement for Categorical Data Data for Categorical of Observer Agreement The Measurement. Biometrics 2011, 33, 159-174. [CrossRef]

43. Kuckartz, U. Qualitative Text Analysis: A Guide to Methods, Practice E Using Software; Sage Publications: Newbury Park, CA, USA, 2014.

44. Libarkin, J.C.; Anderson, S.W. Assessment of learning in entry-level geoscience courses: Results from the Geoscience Concept Inventory. J. Geosci. Educ. 2005. [CrossRef]

45. Creswell, J.W. Research Design: Qualitative, Quantitative and Mixed Method Aproaches; SAGE Publications: Newbury Park, CA, USA, 2007.

46. Bogner, F.X. The Influence of Short-Term Outdoor Ecology Education on Long-Term Variables of Environmental Perspective. J. Environ. Educ. 1998, 29, 17-29. [CrossRef]

47. Kuo, F.E.; Faber Taylor, A. A Potential Natural Treatment for Attention-Deficit/Hyperactivity Disorder: Evidence From a National Study. Am. J. Public Health 2004, 94, 1580-1586. [CrossRef] [PubMed]

48. Kuo, M.; Browning, M.H.E.M.; Penner, M.L. Do lessons in nature boost subsequent classroom engagement? Refueling students in flight. Front. Psychol. 2018, 8, 2253. [CrossRef] [PubMed]

49. Kirschner, P.A. Epistemology, practical work and Academic skills in science education. Sci. Educ. 1992, 1, 273-299. [CrossRef]

50. Di Sessa, A.A. Knowledge in pieces. In Converging Perspectives on Conceptual Change; Routledge: Oxon, UK, 2017 ; pp. 7-16.

51. Chang, N. The Role of Drawing in Young Children's Construction of Science Concepts. Early Child. Educ. J. 2012, 40, 187-193. [CrossRef]

52. Bar, V.; Travis, A.S. Children's views concerning phase changes. J. Res. Sci. Teach. 1991, 28, 363-382. [CrossRef]

53. Zangori, L.; Forbes, C.T.; Schwarz, C.V. Exploring the Effect of Embedded Scaffolding Within Curricular Tasks on Third-Grade Students' Model-Based Explanations about Hydrologic Cycling. Sci. Educ. 2015, 24, 957-981. [CrossRef]

54. Forbes, C.T.; Zangori, L.; Schwarz, C.V. Empirical validation of integrated learning performances for hydrologic phenomena: 3rd-grade students' model-driven explanation-construction. J. Res. Sci. Teach. 2015, 52, 895-921. [CrossRef]

55. Agelidou, E.; Balafoutas, G.; Gialamas, V. Interpreting how third grade junior high school students represent water. Environ. Educ. Inf. 2001, 20, 19-36.

56. Wiggins, G.P.; McTighe, J. Understanding by Design (Expanded 2nd ed); Ascd: Alexandria, VA, USA, $2005 ;$ ISBN 9786468600.

57. Bransford, J.D.; Brown, A.L.; Cocking, R.R. How People Learn: Brain, Mind, Experience, and School; National Academies Press: Washington, DC, USA, 2000. 
58. Lehrer, R.; Schauble, L.; Lucas, D. Supporting development of the epistemology of inquiry. Cogn. Dev. 2008, 23, 512-529. [CrossRef]

59. Boud, D.; Keogh, R.; Walker, D. Promoting reflection in learning: A model. In Reflection: Turning Experience into Learning; Routledge: Oxon, UK, 1985; pp. 18-40. ISBN 0-89397-202-9.

60. Chawla, L. Participation and the Ecology of Environmental Awareness and Action. In Participation and Learning; Springer: Dordrecht, The Netherlands, 2008; pp. 98-110. ISBN 9781402064159.

61. Padilla, K. Visualization: Theory and practice in science education. Int. J. Sci. Educ. 2009, 31, 1417-1420. [CrossRef]

62. Waldrip, B.; Prain, V.; Carolan, J. Using Multi-Modal Representations to Improve Learning in Junior Secondary Science. Res. Sci. Educ. 2010, 40, 65-80. [CrossRef]

63. Quillin, K.; Thomas, S. Drawing-to-Learn: A Framework for Using Drawings to Promote Model-Based Reasoning in Biology. CBE-Life Sci. Educ. 2015, 14, es2. [CrossRef] [PubMed]

64. Pierson, A.E.; Clark, D.B.; Sherard, M.K. Learning progressions in context: Tensions and insights from a semester-long middle school modeling curriculum. Sci. Educ. 2017, 101, 1061-1088. [CrossRef]

65. Kelly, G.J.; Chen, C.; Crawford, T. Methodological considerations for studying science-in-the-making in educational settings. Res. Sci. Educ. 1998, 28, 23-49. [CrossRef]

66. Schwarz, C.V.; Reiser, B.J.; Davis, E.A.; Kenyon, L.; Achér, A.; Fortus, D.; Shwartz, Y.; Hug, B.; Krajcik, J. Developing a learning progression for scientific modeling: Making scientific modeling accessible and meaningful for learners. J. Res. Sci. Teach. 2009, 46, 632-654. [CrossRef]

67. Lave, J.; Wenger, E. Legitimate Peripheral Participation. In Situated Learning; Cambridge University Press: Cambridge, UK, 1991; pp. 27-44.

68. Johnsonlaird, P. Mental models in cognitive science. Cogn. Sci. 1981, 4, 71-115. [CrossRef]

69. Hanson, C. Indigenous Research Methodologies. Int. J. Crit. Indig. Stud. 2012, 5, 93-95. [CrossRef]

70. Kuhn, D.; Pease, M. What needs to develop in the development of inquiry skills? Cogn. Instr. 2008, 26, 512-559. [CrossRef]

71. Kuhn, D.; Black, J.; Keselman, A.; Kaplan, D. The Development of Cognitive Skills To Support Inquiry Learning. Cogn. Instr. 2000, 18, 495-523. [CrossRef]

72. Driver, R.; Guesne, E.; Tiberghien, A. Children's Ideas and the Learning of Science. Child. Ideas Sci. 1985, 1-9. Available online: https://staff.fnwi.uva.nl/e.joling/vakdidactiek/documenten/driver.pdf (accessed on 12 December 2020).

73. Aikenhead, G.S. Science Education: Border Crossing into the Subculture of Science. Stud. Sci. Educ. 1996, 27, 1-52. [CrossRef]

74. Roberts, D.A.; Bybee, R.W. Scientific Literacy, Science Literacy, and Science Education. In Handbook of Research on Science Education, Volume II; Routledge: Oxon, UK, 2014; ISBN 9781136221972. 